\title{
Rule-based classification and mapping of ecosystem services with data on the integrity of forest ecosystems
}

Angela Schlutow ${ }^{1}$ and Winfried Schröder ${ }^{2^{*}}$ (D)

\begin{abstract}
Background: The state of ecosystems influences their services for humans. Therefore, the European Union aims to assess and map ecosystem conditions and ecosystem services at the level of the Union and the Member States to implement maintenance or protection measures, if necessary. This paper examines the relationship between forest ecosystem conditions and ecosystem services at the national level, using Germany as an example. The aim is to create a methodology that allows users to understand and predict how the potential supply of selected ecosystem services might change over time under the influence of climate change and atmospheric nitrogen deposition, and that is reproducible, unlike previous approaches. To this end, the methodology was operationalised in a quantitative and rule-based manner.

Methods and results: The multitude of forest ecosystem types were grouped into 78 classes according to the degree of similarity of their ecological characteristics that influence the provision of ecosystem services. Thereby, ecoclimatic, soil hydrological and nutrient balance characteristics and 12 potential ecosystem service capacities were taken into account. Three potential ecosystem services were quantified for representatives of the ecosystem type classes. The ecosystem service classification was mapped for all of Germany.
\end{abstract}

Conclusions: The methodology presented enables a transparent and thus a reproducible classification of current and future ecosystem services

Keywords: Ecosystem condition, Ecosystem integrity, Ecosystem services, Rule-based ranking of ecosystem services, EU Biodiversity Strategy, Geographic Information System

*Correspondence: Winfried.Schroeder@uni-vechta.de

${ }^{2}$ Chair of Landscape Ecology, University of Vecta, P.O.B. 1553,

49364 Vechta, Germany

Full list of author information is available at the end of the article adaptation, distribution and reproduction in any medium or format, as long as you give appropriate credit to the original author(s) and the source, provide a link to the Creative Commons licence, and indicate if changes were made. The images or other third party material in this article are included in the article's Creative Commons licence, unless indicated otherwise in a credit line to the material. If material is not included in the article's Creative Commons licence and your intended use is not permitted by statutory regulation or exceeds the permitted use, you will need to obtain permission directly from the copyright holder. To view a copy of this licence, visit http://creativeco mmons.org/licenses/by/4.0/. 


\section{Background}

Ecosystem services are the benefits that people receive from ecosystems. They depend on ecosystem structures (e.g., biotic and abiotic ecosystem elements) and on their energetic and material relationships, i.e., their functions, and on the biological, chemical and physical processes (processes) underlying them. If ecosystem structures and functions move away from a defined reference state, stages of change in ecosystem integrity up to the replacement of one ecosystem type by another can be illustrated using quantitative data from environmental monitoring and modelling $[1,2]$. Ecosystem integrity determines the provision of ecosystem services such as regulating services (e.g., nutrient, climate regulation, erosion control), supply services (e.g., food, water, fuels) and cultural services (e.g., recreation, landscape aesthetics) [3].

Among a bunch of environmental factors, climate change and atmospheric nitrogen deposition can change the integrity of ecosystems, i.e., their structures and functions, and thereby also limit their benefits for humans, the ecosystem services [4]. Jenssen et al. [1,2] presented a spatially explicit concept for classifying changes in ecosystem integrity on different spatial levels. This methodology enables an integrative assessment of changes in ecosystem integrity. It was based on an extensive vegetation database, nationally available data from maps and long-term monitoring programmes. It is supplemented by dynamic modelling of future climate and soil conditions. This approach supplements existing assessment procedures coping with ecosystem conditions and integrity by more strongly incorporating abiotic environmental factors and their changes as drivers of ecosystem integrity.

According to Objective 2 Measure 5 of the European Biodiversity Strategy [5], all EU Member States are required to "map and assess the state of ecosystems and their services in their national territory" ([5], p. 5). Methodological guidelines were developed to support the individual EU member states in implementing this measure $[6,7]$. For example, the classification of ecosystem servicves can be achieved using the so-called matrix method [8]. Here, the ecosystem services are classified according to a relative scale of $0-5(0=$ not significant, $5=$ very high) and linked with different spatial mapping units [9]. The method has, therefore, already been applied in numerous studies and is constantly being further developed [9-11]. The EU recommends the method for spatial representation and "rapid assessment" (Jacobs et al. 2015) of ecosystem services in the framework of the European Biodiversity Strategy [12].

A methodological problem of the matrix method is that the ordination of is not always based on quantitative information and is not rule-based. Methodological transparency is often lacking as a prerequisite for objective, reliable (reproducible) and valid results [13]. In addition, the publications on the application of the matrix method lack information on the scatter range of expertbased ratings, this would be a measure of the objectivity of the method, and repeated assessments by the same experts would allow its reproducibility to be assessed. Consequently, Sohel et al. [11] emphasised the methodologically necessary consideration of quantitative biophysical indicators and empirical modelling. Therefore, the aim of this contribution is to develop and present a methodology with which ecosystem services can be classified and mapped in a rule-based, transparent and automated way on the basis of monitoring data and data modelled for projections for Germany as a whole, for regions (e.g., Kellerwald National Park, German federal state Hesse) and individual forest locations. In this article this is done rule-based for up to 14 ecosystem services according to the Common International Classification of Ecosystem Services [14].

The CICES catalog of ecosystem services [14] forms the common basis for recording ecosystem services at the European level (Table 1).

\section{Methods}

The basic function of the presented methodology is rule-based classification. Rule-based classifiers are just another type of classifier which makes the class decision depending using various "if ... else" rules [16]. These rules are easily interpretable and thus these classifiers are generally used to generate descriptive models. Thereby, a continuous (or quasi-continuous) characteristic may be treated as a discrete characteristic or a cardinally scaled characteristic is transformed into an ordinally scaled characteristic. This may be appropriate for several reasons. In this case, characteristic values are combined into groups or classes, e.g., because each value occurs too rarely or is used in automated rules. This process is also called grouping (= classification) of data or data binning. Discrete binning or bucketing is a data pre-processing technique used to reduce the effects of minor observation errors. The original data values which fall into a given small interval, a bin, are replaced by a value representative of that interval, often the central value. A grouping/classification is usually accompanied by a loss of information, since the measurement accuracy is artificially reduced. However, if necessary, the representation and possibly also the statistical processing is simplified. Each classification corresponds basically to a transformation at least back to the ordinal scale. The property of the cardinal scale, namely that the distances are measurable and sensibly interpretable, is actually lost. Nevertheless, it should be kept in mind that the presented methodology 
Table 1 Classification of ecosystem services relevant in Germany according to CICES (slightly modified after Albert et al. [15])

\begin{tabular}{|c|c|c|}
\hline \multicolumn{3}{|l|}{ Regulation and maintenance services } \\
\hline \multirow[t]{4}{*}{ Mass movement regulation } & Resistance to (solid) mass movement & $\begin{array}{l}\text { Stabilization of solid masses (soil, sand, snow, etc.), } \\
\text { regulation of soil erosion }\end{array}$ \\
\hline & \multirow[t]{3}{*}{ Regulation of water balance and runoff } & Flood protection \\
\hline & & Groundwater recharge/drinking water supply \\
\hline & & $\begin{array}{l}\text { Groundwater protection/assurance of drinking } \\
\text { water quality }\end{array}$ \\
\hline \multirow[t]{4}{*}{$\begin{array}{l}\text { Maintenance of physical, chemical and biologi- } \\
\text { cal conditions }\end{array}$} & Habitat function & $\begin{array}{l}\text { Self-regulation and self-organization of ecosys- } \\
\text { tems }\end{array}$ \\
\hline & Buffering of foreign matter inputs & Contribution to global climate regulation \\
\hline & Contribution to global climate regulation & Carbon storage function \\
\hline & $\begin{array}{l}\text { Improvement of air quality and climate regula- } \\
\text { tion }\end{array}$ & Regulation of micro, local and regional climate \\
\hline \multicolumn{3}{|l|}{ Utility services } \\
\hline Food & Plant and animal food production & Crops and products \\
\hline Raw materials & Production of plant and animal raw materials & Plant and animal raw materials \\
\hline Energy & Production of energetically usable biomass & Vegetable energy raw materials \\
\hline \multicolumn{3}{|l|}{ Cultural achievements } \\
\hline \multirow[t]{2}{*}{$\begin{array}{l}\text { Physical and cognitive experience of living } \\
\text { beings, landscape spaces and landscapes }\end{array}$} & $\begin{array}{l}\text { Recreational function—physical and experiential } \\
\text { experiences }\end{array}$ & Nature experience and recreation \\
\hline & Cognitive and emotional interaction & $\begin{array}{l}\text { Sensation of aesthetics, nature education, natural } \\
\text { heritage }\end{array}$ \\
\hline $\begin{array}{l}\text { Symbolic meaning of living beings, landscape } \\
\text { spaces and landscapes }\end{array}$ & Symbolic meaning, other cultural achievements & Cultural heritage, legacy to future generations \\
\hline
\end{tabular}

explicates in detail the classification/binning of the data and their ordination required for rule generation. In contrast to the matrix method, this transparency makes any classification of ecosystem integrity and ecosystem services agent-independent (objective) and thus reproducible at any time. The presented method is, therefore, objective, reproducible (reliable) and construct valid.

The aim of ecosystem services assessment is to derive the need for, and the type and extent of, measures to restore the highest possible performance by comparing the performance potentials in the reference state with the current or predicted performance of an ecosystem. For this purpose, it is necessary to define the evaluation criteria on the basis of measurable parameters so that the derivation of the evaluation is comprehensible and the results are repeatable. Only an assessment of current ecosystem services based on clearly determinable parameters makes it possible to objectively assess the deviation from the performance potential of the ecosystem and thus to derive a realistic need for action to restore the possible performance. The following scheme (Fig. 1) shows the process according to which the methodology presented here is applied. The first step for a rule-based assessment of ecosystem services (ECOS) consists of a rule-based classification of ecosystem types. The second step includes the qualitative assessment of the ECOS for each ecosystem type. Retrospectively, in the third step, the performed classification of ecosystem types has to be reviewed on the basis of the differentiated assessment of the ecosystem services and adjusted if necessary.

\section{Classification of forest ecosystem types in Germany}

The classification of ecosystem types into ecosystem type classes should be done with the aim of grouping together ecosystem types with similar vegetation types (species composition, structure and use) and similar site parameters, if they also have qualitatively and quantitatively comparable ecosystem service potentials. As few ecosystem type classes as possible should be segregated to ensure clarity, but as many as necessary to ensure clear delineation from each other in terms of site characteristics, vegetation type, and ecosystem integrity. Forest ecosystem types can be unambiguously assigned to site types in Germany if they are defined by a combination of ecoclimatic zones, soil moisture stage and nutrient cycle type $[1,2,17]$. This is described in the following.

The climate classification is based on plant-geographical distribution patterns of near-natural forest plant communities or their main tree species and assignment of ranges of mean annual temperature and total annual precipitation (Table 2). In this way, the climate classification can be traced at any time using the original DWD data [18] and, if necessary, updated (e.g., 1991-2020). 


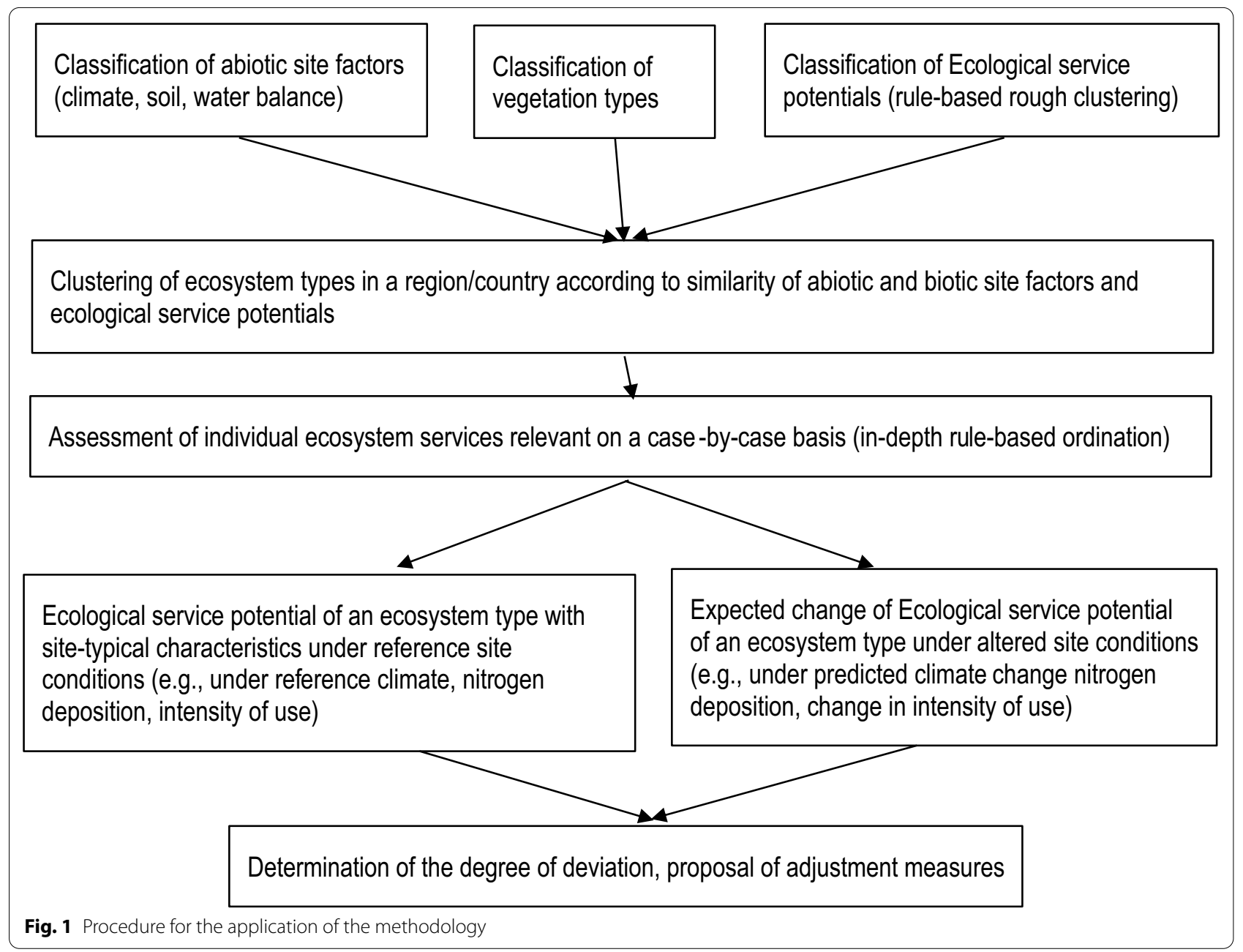

Table 2 Eco-climatic zones based on annual mean temperature and annual total precipitation (according to BMVBS [19]) using the distribution of the main tree species in Germany

\begin{tabular}{|c|c|c|}
\hline Ecoclimatic zones & $\begin{array}{l}\text { Annual mean temperature } \\
1981-2010\left({ }^{\circ} \mathrm{C}\right)\end{array}$ & $\begin{array}{l}\text { Annual precipitation } \\
\text { total 1981-2010 } \\
\left(\mathrm{mm} \mathrm{a}^{-1}\right)\end{array}$ \\
\hline 1. Moderate mountain climate (mountain pine, larch, spruce, fir) & -4 to 8 & 1065 to 2710 \\
\hline 2. Temperate sub-oceanic climate, partly mountain climate (beech, partly fir) & 4.7 to 11.1 & 745 to 1291 \\
\hline $\begin{array}{l}\text { 2-3 (2.5). Temperate sub-oceanic to temperate subcontinental climate, partly mountain } \\
\text { climate (beech) }\end{array}$ & 5.5 to 11.1 & 514 to 854 \\
\hline $\begin{array}{l}\text { 3. Temperate central European to subcontinental climate (oaks, Scots pine, hornbeam, } \\
\text { limetree) }\end{array}$ & 8.1 to 12 & 380 to 632 \\
\hline
\end{tabular}

The classification of soil moisture levels was also based on plant physiological aspects.The volumetric water content in the topsoil $\left(\mathrm{m}^{3}\right.$ water $/ \mathrm{m}^{3}$ soil) refers to the range of field capacity in the effective rooting zone. The lower range limit given in Table 3 for the anhydromorphic soil forms results from the water content at the permanent wilting point at $\mathrm{pF}=4.2$ ([20], p. 350), the upper range limit at saturated field capacity, i.e., at $\mathrm{pF}=1.8$. The range given in Table 3 for the hydromorphic soil forms results from the water content at $\mathrm{pF}$ 0.5-1.8.

The classification of the nutrient cycle types of Germany's forest ecosystems was based on the $\mathrm{C} / \mathrm{N}$ ratio in the 
Table 3 Moisture levels based on volumetric water content following Schulze [21]

\begin{tabular}{ll}
\hline Moisture classes & $\begin{array}{l}\text { Volumetric water } \\
\text { content, annual average } \\
\left(\mathrm{m}^{3} \mathrm{~m}^{-3}\right)\end{array}$ \\
\hline 1. Dry & $\leq 0.05$ to 0.15 \\
2. Moderately dry to fresh & 0.14 to 0.3 \\
3. Moist, humid & 0.3 to 0.42 \\
4. Wet & 0.42 to 0.66 \\
5. Alternately dry to fresh, flooded & 0.21 to 0.3 \\
6. Moist-flooded & 0.3 to 0.52 \\
7. Very wet & 0.5 to 0.97 \\
\hline
\end{tabular}

topsoil (averaged over humus topsoil $+5 \mathrm{~cm}$ mineral topsoil) and base saturation (averaged over the entire rooting zone) following Jenssen et al. [1, 2], supplemented from Sucoow, [22-24]. The nomenclature of the groups is based on Schulze [21] (Table 4).

The grouping of forest ecosystem types by main tree species was based on the mapping of forest types in the Corine Land Cover data base for Germany [1, 25] (Table 5).

\section{Linking ecosystem type classes reference states with ecosystem services}

The 78 ecosystem type classes were then linked with the respective data on the reference state by applying transparent rules enabling the reproduction of the results. To evaluate the potential of ecosystem services of the 78 ecosystem type classes the relevant CICES classes (Table 1) were applied, refined, and underscored. The rating scale is broken down into 6 value levels:
$0=$ Ecosystem services potential of no importance.

$1=$ Ecosystem services potential with low significance.

$2=$ Ecosystem services potential with moderate significance.

$3=$ Ecosystem services potential with medium significance.

$4=$ Ecosystem services potential with high significance.

$5=$ Ecosystem services potential with very high significance.

The habitat function, the carbon storage function and the primary biomass production were examined in more detail, i.e., the ordinal scales for the criteria are underpinned with measurement data. The other functions listed here (Table 6) were initially evaluated here "only" by means of a rough expert estimate but not always based on measured data.

The evaluation was carried out for each of the 78 ecosystem type classes for each ecosystem service class on the basis of the above criteria (Table 6). The criteria were weighted for evaluation according to the order in which they were mentioned. First, the first-mentioned criterion was assessed according to the ordinal rating scale in Table 6, then additions or deductions were made for the subsequent criteria.

The assessment of ecosystem service potentials according to the ordinal scale in Table 6 took into account the general relative value of forests and woodlands within an assessment framework for a variety of land use types. Thus, for example, ecosystem service potentials that a forest generally cannot fulfill as well as grassland or

Table 4 Classes of nutrient cycle types based on C/N ratio and base saturation according to Schulze [21]

\begin{tabular}{|c|c|c|}
\hline Classes of nutrient cycle types & C/N (\%/\%) & Base saturation (\%) \\
\hline 1. Poor & 29 to 50 & 3 to 15 \\
\hline 2. Quite poor & 26 to 33 & 10 to 20 \\
\hline 3. Moderately nutritious & 17 to 26 & 15 to 30 \\
\hline 4. Moderately nutritious, carbonate-containing & 17 to 21 & $>90$ \\
\hline 5. Vigorous nutritious & 13 to 18 & 30 to 50 \\
\hline 6. Vigorous nutritious, carbonate-containing & 13 to 15 & $>90$ \\
\hline 7. Nutrient-rich & 11 to 14 & 50 to 80 \\
\hline 8. Nutrient-rich, carbonate-containing & 8 to 11 & 80 to 100 \\
\hline 9. Poor, organic & 30 to 60 & $<26$ \\
\hline 10. Quite poor, organic & 26 to 36 & $<26$ to 52 \\
\hline 11. Moderately nutritious, organic & 20 to 26 & $<26$ to 52 \\
\hline 12. Vigorous nutritious, organic & 13 to 20 & $>26$ \\
\hline 13. Nutrient-rich, carbonate-containing, organic & $<10$ to 30 & $>90$ \\
\hline 14. Quite poor, carbonate-containing, organic & 20 to 31 & $>52$ \\
\hline
\end{tabular}


Table 5 Result of classification of forest ecosystems based on abiotic site factors and forest types

\begin{tabular}{|c|c|c|c|c|}
\hline $\begin{array}{l}\text { Ecoclimatic } \\
\text { zones }\end{array}$ & $\begin{array}{l}\text { Soil } \\
\text { moisture } \\
\text { stage }\end{array}$ & $\begin{array}{l}\text { Nutrient } \\
\text { cycle } \\
\text { type }\end{array}$ & $\begin{array}{l}\text { Forest type } \\
\text { (CORINE Land } \\
\text { Cover) }\end{array}$ & Forest ecosystem type class \\
\hline 3 & 1 & 1 & Coniferous & 1. Central european to sub-continental, dry, nutrient-poor pine forest \\
\hline 2 & 1 & 1 & Mixed & 2. Sub-oceanic, dry, nutrient-poor pine wood \\
\hline 3 & 1 & 1 & Mixed & 3. Central european to sub-continental, dry, nutrient-poor pine wood \\
\hline 2 & 2 & 1 & Coniferous & 4. Sub-oceanic, moderately dry to fresh, nutrient-poor pine forest \\
\hline 2 & 2 & 1 & Coniferous & 5. Sub-oceanic, moderately dry to fresh, poor larch forest \\
\hline 2 & 2 & 1 & Deciduous & 6. Sub-oceanic, moderately dry to fresh, nutrient-poor beech wood/forest \\
\hline 2 & 2 & 1 & Mixed & 7. Sub-oceanic, moderately dry to fresh, nutrient-poor spruce wood \\
\hline 2 & 2 & 1 & Coniferous & 8. Sub-oceanic, moderately dry to fresh, nutrient-poor spruce forest \\
\hline 2 & 4 & 1 & Coniferous & 9. Sub-oceanic, moist, nutrient-poor pine forest \\
\hline 2 & 4 & 2 & Coniferous & 10. Sub-oceanic, moist, quite nutrient-poor pine forest \\
\hline 3 & 4 & 1 & Mixed & 11. Central european to sub-continental, moist, nutrient-poor spruce wood \\
\hline 3 & 1 & 2 & Deciduous & 12. Central european to sub-continental, dry, quite nutrient-poor sessile oak wood \\
\hline 3 & 1 & 2 & Coniferous & 13. Central european to sub-continental, dry, quite nutrient-poor pine forest \\
\hline 2 & 2 & 2 & Deciduous & 14. Sub-oceanic, moderately dry to fresh, quite nutrient-poor beech wood/forest \\
\hline 1 & 2 & 2 & Deciduous & 15. moderate mountain climate, moderately dry to fresh, quite nutrient-poor beech wood/forest \\
\hline 2 & 4 & 2 & Deciduous & 16. Sub-oceanic, moist, quite nutrient-poor pedunculate oak forest \\
\hline 2 & 5 & 2 & Mixed & 17. Sub-oceanic, wet, quite nutrient-poor fir wood \\
\hline 3 & 1 & 3 & Coniferous & 18. Central european to sub-continental, dry, moderately nutritious pine forest \\
\hline 3 & 1 & 3 & Deciduous & 19. Central european to sub-continental, dry, moderately nutritious sessile oak wood \\
\hline 2 & 2 & 3 & Coniferous & 20. Sumb-oceanic, moderately dry to fresh, moderately nutritious pine forest \\
\hline 3 & 2 & 3 & Coniferous & $\begin{array}{l}\text { 21. Central european to sub-continental, moderately dry to fresh, moderately nutritious pine } \\
\text { forest }\end{array}$ \\
\hline 2 & 4 & 3 & Deciduous & 22. Sub-oceanic, moist, moderately nutritious oak forest \\
\hline 2 & 1 & 4 & Coniferous & 23. Sub-oceanic, dry, moderately nutritious carbonate-containing pine forests of alpine valleys \\
\hline 2 & 2 & 3 & Deciduous & 24. Sub-oceanic, moderately dry to fresh, moderately nutritious beech forest/wood \\
\hline 3 & 2 & 3 & Deciduous & $\begin{array}{l}\text { 25. Central european to sub-continental, moderately dry to fresh, moderately nutritious sessile } \\
\text { oak-beech wood }\end{array}$ \\
\hline 3 & 2 & 3 & Deciduous & $\begin{array}{l}\text { 26. Central european to sub-continental, moderately dry to fresh, moderately nutritious lime- } \\
\text { hornbeam wood }\end{array}$ \\
\hline 1 & 2 & 3 & Deciduous & $\begin{array}{l}\text { 27. moderate mountain climate, moderately dry to fresh, moderately nutritious beech wood/ } \\
\text { forest }\end{array}$ \\
\hline 2 & 2 & 3 & Coniferous & 28. Sub-oceanic, moderately dry to fresh, moderately nutritious spruce forest \\
\hline 2 & 2 & 3 & Mixed & 29. Sub-oceanic, moderately dry to fresh, moderately nutritious spruce-fir-Wood \\
\hline 2 & 2 & 3 & Coniferous & 30. Sub-oceanic, moderately dry to fresh, moderately nutritious douglas fir forest \\
\hline 2 & 2 & 3 & Mixed & 31. Sub-oceanic, moderately dry to fresh, moderately nutritious fir-beech forest \\
\hline 2 & 2 & 3 & Deciduous & 32. Sub-oceanic, moderately dry to fresh, moderately nutritious pedunculate oaks -beech wood \\
\hline 2 & 2 & 3 & Deciduous & 33. Sub-oceanic, moderately dry to fresh, moderately nutritious oak forest \\
\hline 1 & 4 & 3 & Mixed & 34. Moderate mountain climate, moist, moderately nutritious fir-beech-wood \\
\hline 2 & 4 & 3 & Mixed & 35. Sub-oceanic, moist, moderately nutritious fir-beech-wood \\
\hline 2 & 4 & 3 & Deciduous & 36. Sub-oceanic, humid, moderately nutritious oak hornbeam forest \\
\hline 2 & 5 & 3 & Mixed & 37. Sub-oceanic, wet, moderately nutritious fir wood \\
\hline 2 & 1 & 4 & Coniferous & 38. Sub-oceanic, dry, moderately nutritious carbonate-containing pine forest \\
\hline 2 & 2 & 4 & Coniferous & $\begin{array}{l}\text { 39. Sub-oceanic, moderately dry to fresh, moderately nutritious carbonate-containing spruce } \\
\text { forest }\end{array}$ \\
\hline 3 & 1 & 5 & Deciduous & 40. Central european to sub-continental, dry, vigorous nutritious Rock maple -sessile oak-wood \\
\hline 3 & 2 & 5 & Deciduous & $\begin{array}{l}\text { 41. Central european to sub-continental, moderately dry to fresh, vigorous nutritious hornbeam } \\
\text { wood/forest }\end{array}$ \\
\hline 3 & 2 & 5 & Deciduous & $\begin{array}{l}\text { 42. Central european to sub-continental, moderately dry to fresh, vigorous nutritious winter lime } \\
\text { wood }\end{array}$ \\
\hline 1 & 2 & 5 & Mixed & 43. Moderate mountain climate, moderately dry to fresh, vigorous nutritious spruce-fir-wood \\
\hline
\end{tabular}


Table 5 (continued)

\begin{tabular}{|c|c|c|c|c|}
\hline $\begin{array}{l}\text { Ecoclimatic } \\
\text { zones }\end{array}$ & $\begin{array}{l}\text { Soil } \\
\text { moisture } \\
\text { stage }\end{array}$ & $\begin{array}{l}\text { Nutrient } \\
\text { cycle } \\
\text { type }\end{array}$ & $\begin{array}{l}\text { Forest type } \\
\text { (CORINE Land } \\
\text { Cover) }\end{array}$ & Forest ecosystem type class \\
\hline 2 & 2 & 7 & Deciduous & 44. Sub-oceanic, moderately dry to fresh, nutrient-rich beech wood/forest \\
\hline 2 & 4 & 5 & Deciduous & 45. Sub-oceanic, moist, vigorous nutritious Sycamore maple and ash wood of the montane level \\
\hline 2 & 2 & 5 & Deciduous & 46. Sub-oceanic, moderately dry to fresh, vigorous nutritious oak forest \\
\hline 2 & 4 & 5 & Deciduous & 47. Sub-oceanic, moist, vigorous nutritious beech wood/forest \\
\hline 2 & 4 & 7 & Deciduous & 48. Sub-oceanic, moist, nutrient-rich oak-hornbeam-ash wood \\
\hline 2 & 5 & 7 & Deciduous & 49. Sub-oceanic, wet, nutrient-rich black alder floodplain wood \\
\hline 2 & 7 & 5 & Deciduous & 50. Sub-oceanic, moist-flooded, vigorous nutritious alluvial elm and penunculate oak wood \\
\hline 2 & 2 & 7 & Deciduous & 51. Sub-oceanic moderately dry to fresh, nutrient-rich oak alternating dry wood \\
\hline 3 & 2 & 7 & Deciduous & 52. Central european to sub-continental, moderately dry to fresh, nutrient-rich winter lime wood \\
\hline 1 & 2 & 7 & Deciduous & $\begin{array}{l}\text { 53. Moderate mountain climate, moderately dry to fresh, nutrient-rich sycamore maple -beech } \\
\text { wood }\end{array}$ \\
\hline 2 & 2 & 7 & Deciduous & 54. Sub-oceanic, moderately dry to fresh, nutrient-rich hornbeam-beech-wood \\
\hline 3 & 2 & 7 & Deciduous & $\begin{array}{l}\text { 55. Central european to sub-continental, moderately dry to fresh, nutrient-rich hornbeam-beech- } \\
\text { wood }\end{array}$ \\
\hline 2 & 2 & 7 & Deciduous & 56. Sub-oceanic, moderately dry to fresh, nutrient-rich beech wood/forest \\
\hline 2 & 2 & 7 & Deciduous & $\begin{array}{l}\text { 57. Sub-oceanic, moderately dry to fresh, nutrient-rich mountain elm- summer lime trees block } \\
\text { wood }\end{array}$ \\
\hline 2 & 4 & 7 & Deciduous & 58. Sub-oceanic, moist, nutrient-rich beech wood/forest \\
\hline 2 & 4 & 7 & Deciduous & 59. Sub-oceanic, moist, nutrient-rich ash wood \\
\hline 2 & 7 & 7 & Deciduous & 60. Sub-oceanic, moist-flooded, nutrient-rich alluvial wood with Salix $\times$ rubens \\
\hline 2 & 1 & 8 & Deciduous & 61. Sub-oceanic, dry, nutrient-rich, carbonate-containing sessile oak rock dry forest \\
\hline 2 & 1 & 8 & Deciduous & 62. Sub-oceanic, dry, nutrient-rich carbonate-containing oak wood \\
\hline 2 & 2 & 8 & Deciduous & $\begin{array}{l}\text { 63. Sub-oceanic, moderately dry to fresh, nutrient-rich carbonate-containing sunny slope beech } \\
\text { wood/forest }\end{array}$ \\
\hline 2 & 2 & 8 & Deciduous & 64. Sub-oceanic, moderately dry to fresh, nutrient-rich carbonate-containing beech wood/forest \\
\hline 2 & 4 & 8 & Deciduous & 65. Sub-oceanic, moist, nutrient-rich carbonate-containing ash wood \\
\hline 1 & 8 & 9 & Deciduous & 66. Moderate mountain climate, very wet, nutrient-poor organic raised bog \\
\hline 2 & 8 & 9 & Deciduous & 67. Sub-oceanic, very wet, nutrient-poor organic raised bog \\
\hline 1 & 5 & 10 & Deciduous & 68. Moderate mountain climate, wet, quite nutrient-poor organic raised bog-wood \\
\hline 1 & 5 & 10 & Deciduous & 69. Moderate mountain climate, wet, quite nutrient-poor organic Carpathian birch wood \\
\hline 3 & 5 & 10 & Deciduous & 70. Central European to sub-continental, wet, quite nutrient-poor organic bog birch wood \\
\hline 2 & 4 & 11 & Deciduous & 71. Sub-oceanic, moist, moderately nutritious organic black alder wood \\
\hline 2 & 5 & 11 & Deciduous & 72. Sub-oceanic, wet, moderately nutritious organic black alder wood \\
\hline 2 & 5 & 12 & Deciduous & 73. Sub-oceanic, wet, vigorous nutritious organic black alder wood \\
\hline 2 & 7 & 12 & Deciduous & 74. Sub-oceanic, moist-flooded, vigorous nutritious organic grey alder wood \\
\hline 2 & 7 & 12 & Deciduous & 75. Sub-oceanic, moist-flooded, vigorous nutritious organic Prunus padus-ash wood \\
\hline 1 & 2 & 14 & Coniferous & $\begin{array}{l}\text { 76. Moderate mountain climate, moderately dry to fresh, quite nutrient-poor carbonate-contain- } \\
\text { ing mountain pine crooked wood }\end{array}$ \\
\hline 1 & 2 & 14 & Coniferous & $\begin{array}{l}\text { 77. Moderate mountain climate, moderately dry to fresh, quite nutrient-poor carbonate-contain- } \\
\text { ing spruce wood }\end{array}$ \\
\hline 1 & 2 & 14 & Mixed & $\begin{array}{l}\text { 78. Moderate mountain climate, moderately dry to fresh, quite nutrient-poor carbonate-contain- } \\
\text { ing spruce-beech wood }\end{array}$ \\
\hline
\end{tabular}

arable land (e.g., groundwater recharge function) were evaluated with value levels $<5$, while other ecosystem service potentials that can only be maximally realised in forests (e.g., climatic-ecological and air-hygienic balancing function) were generally assigned value levels $>1$.
The method serves the user in particular to classify status information to estimate possible deviations of the current status from the reference status in the concrete individual case. Thus, users can identify the influencing 


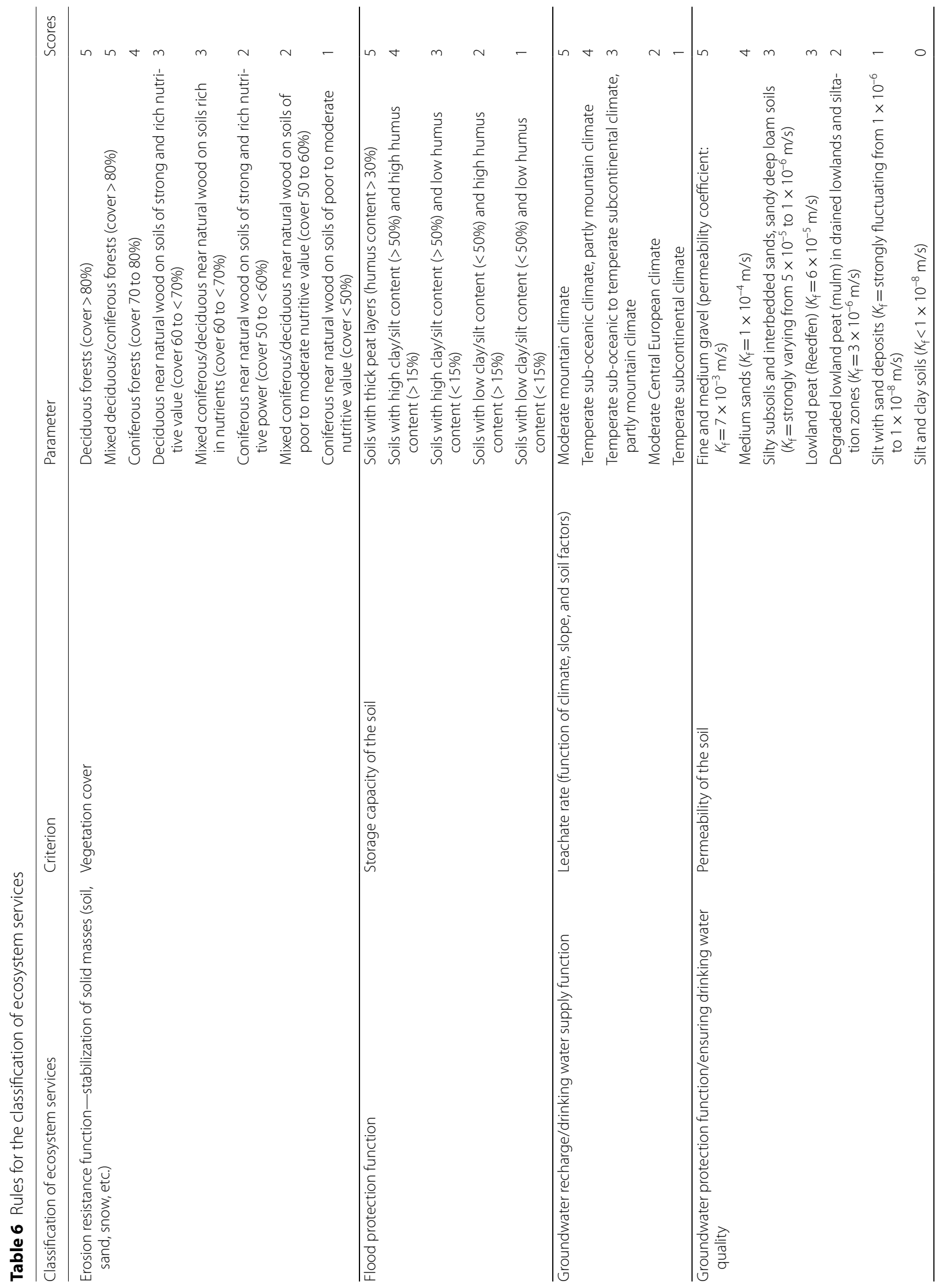


Schlutow and Schröder Environ Sci Eur ～(2021) 33:50

Page 9 of 34

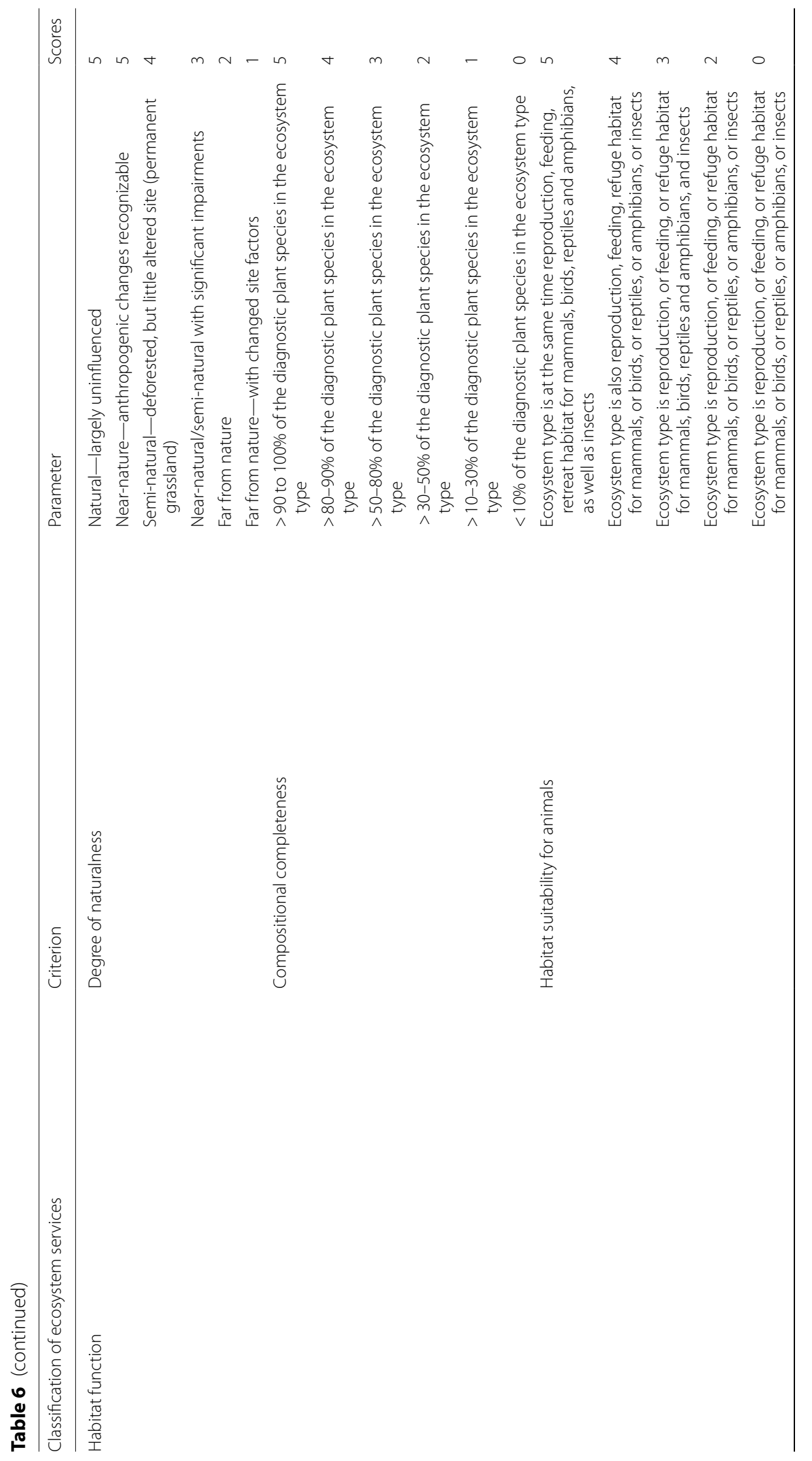




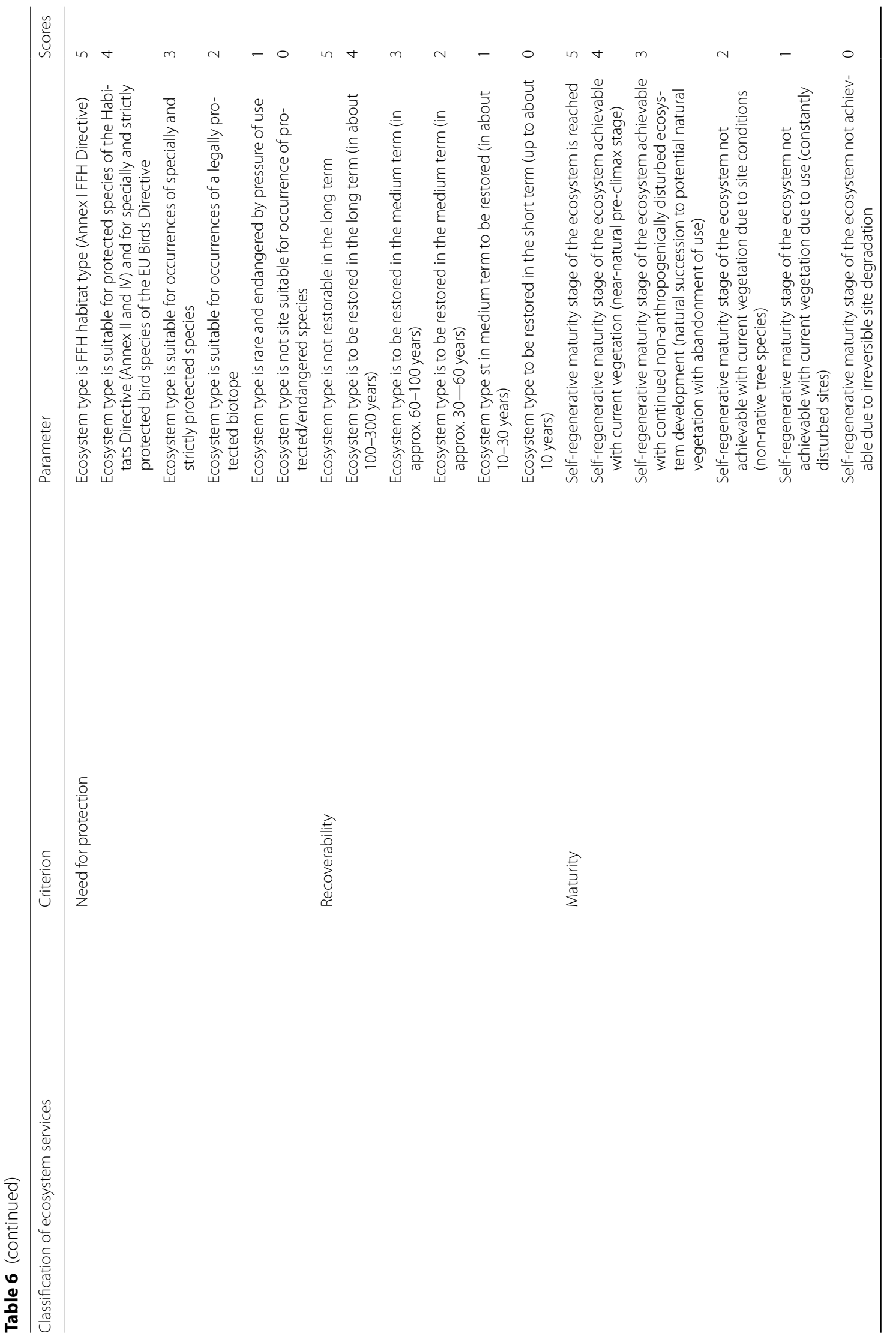




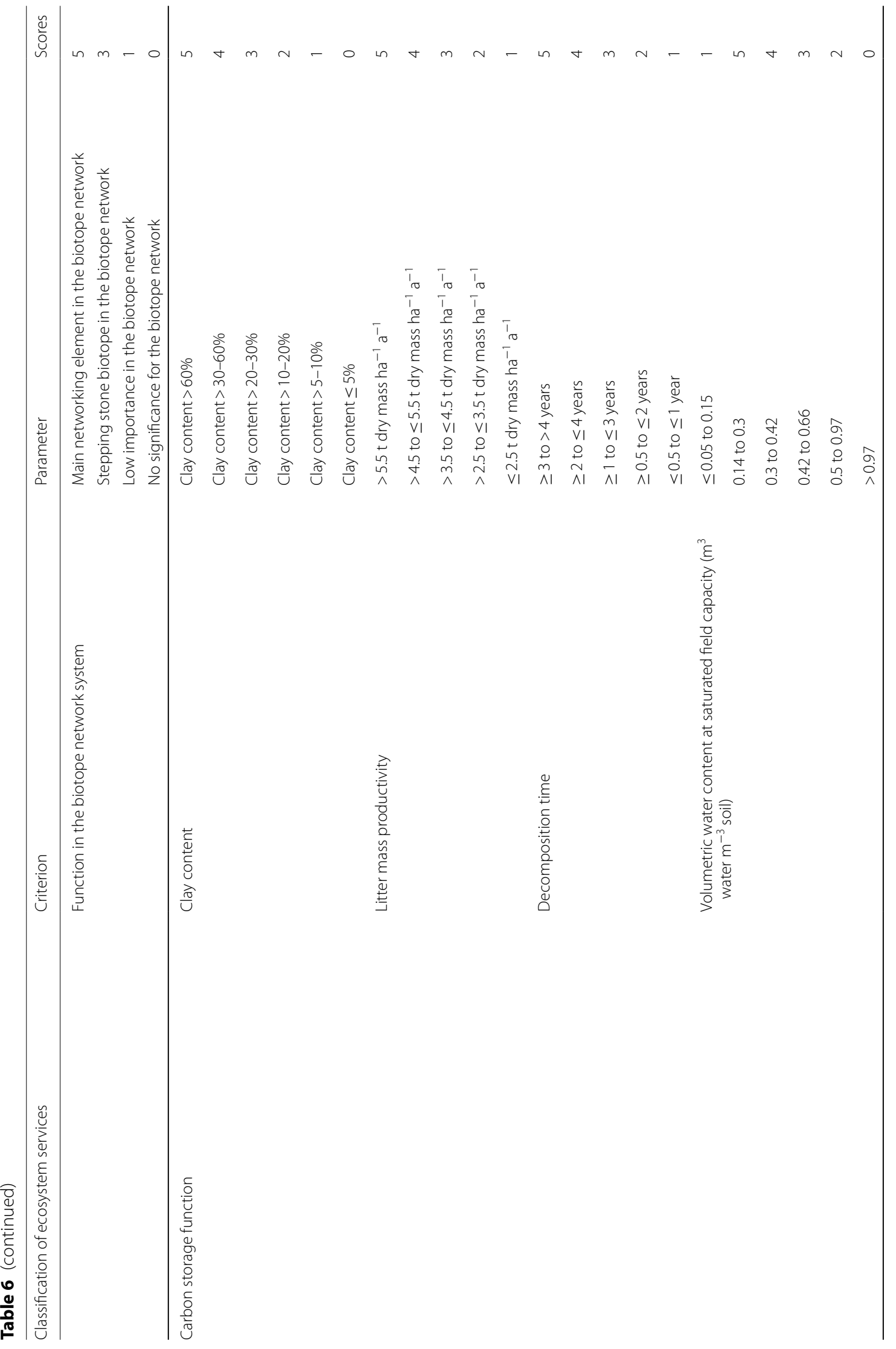


Schlutow and Schröder Environ Sci Eur ～(2021) 33:50

Page 12 of 34

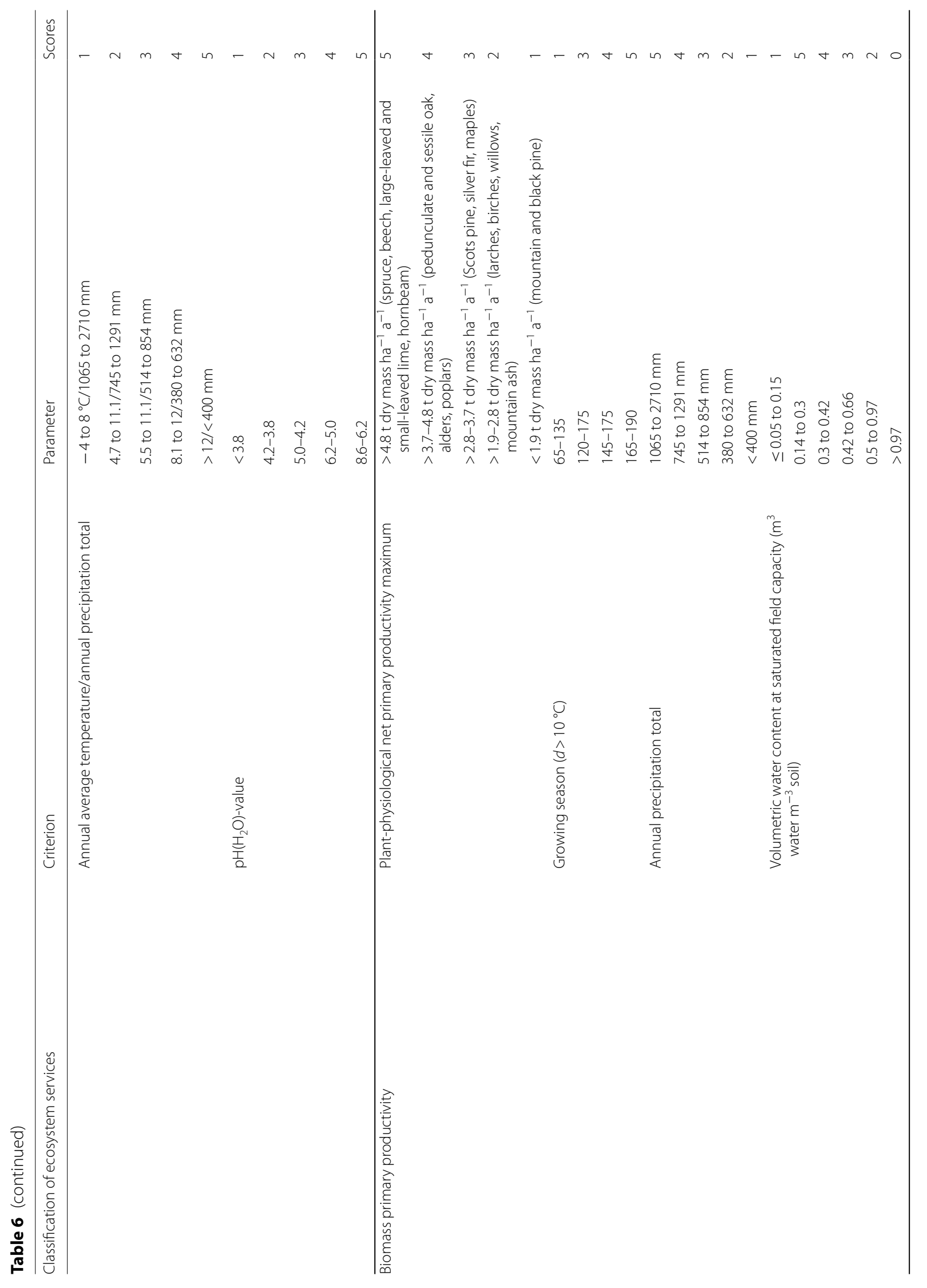


Schlutow and Schröder Environ Sci Eur ～(2021) 33:50

Page 13 of 34

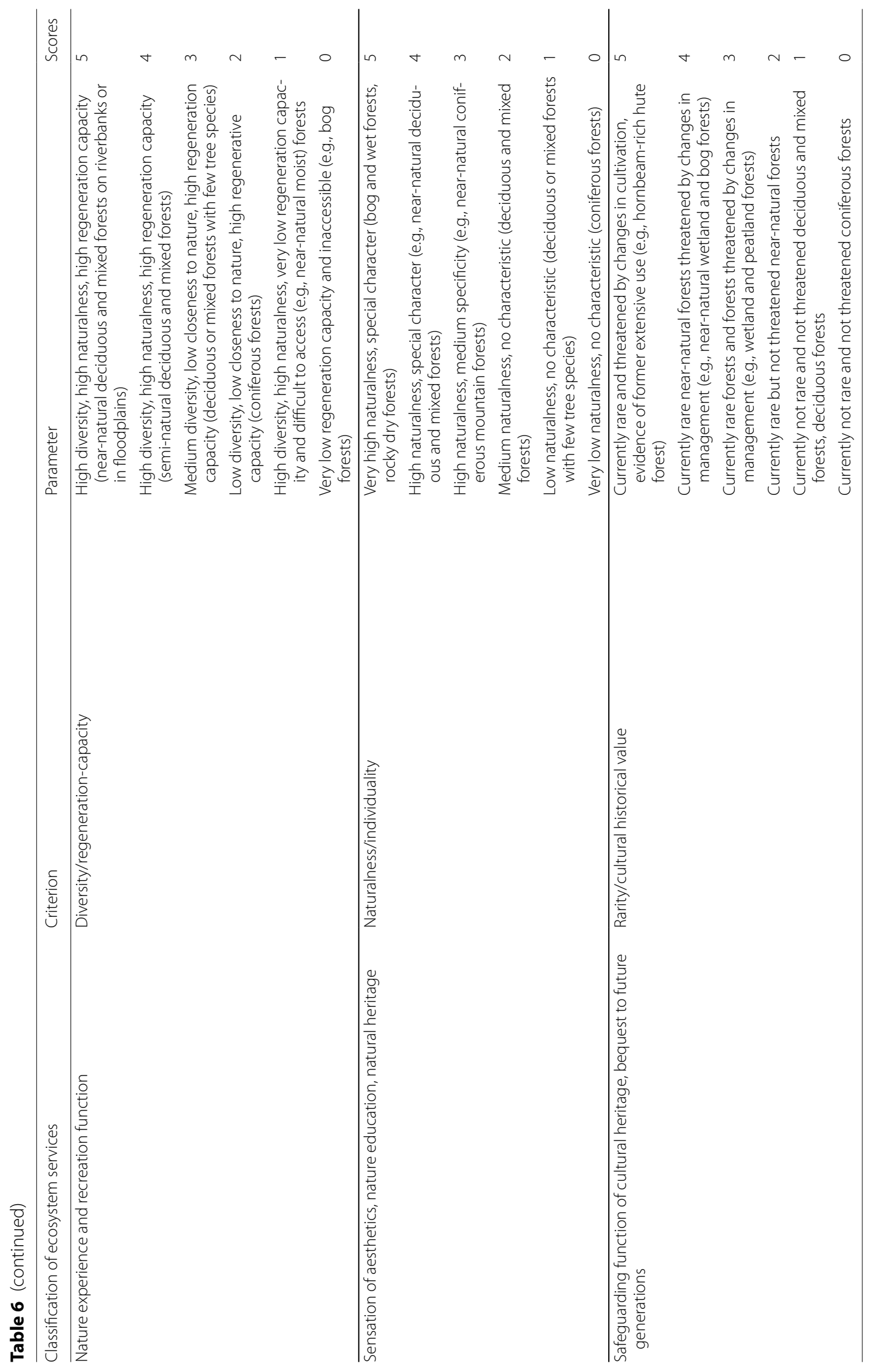


factor that significantly causes the degree of deviation of the current service function from the service potential in the reference status and derive the strategy for effective restoration measures of the ecosystem services potential from this.

\section{In-depth analysis of the three most important ecosystem services}

The analysis focused on the following three ecosystem services:

1. Habitat function (classified by CICES as "self-regulation and self-organisation of ecosystems", Table 6);

2. Carbon storage function (for CICES to be assigned to the "contribution to global climate regulation", Table 6);

3. Primary biomass production (tree wood) (classified in the CICES class "vegetable and animal raw materials", Table 6).

These three ecosystem services were selected, because they are exemplary and significant for regulatory and maintenance services and of nationwide and regional importance. The aim of the classification of the ecosystem services was to derive the necessity as well as the type and scope of measures for restoring the highest possible efficiency by comparing the ecosystem service potentials in the reference state with current and probable future ecosystem services potentials. For this purpose, it was necessary to underpin the ecosystem services classification rule-based, if possible on the basis of quantitative indicators, so that the procedure is comprehensible and transparent and the results reproducible. Only such a transparent, quantitative methodology for the classification of ecosystem services makes it possible to objectively determine the deviation from the ecosystem services potential in the reference state and thus to determine a realistic need for action to restore the ecosystem services potential. It is true that the smaller the deviation of the currently detectable (possibly anthropogenically impaired) ecosystem services from the potential of services of the ecosystem type class in the reference state, the higher the functional capacity of the ecosystem is to be ordinate. The prerequisite for this was first of all an assessment of the potential service of the ecosystem type class in its reference state, as illustrated below using three ecosystem services as examples. The information bases for this are the data used for the quantitative description and Germany-wide mapping of ecosystem type classes, land use data (Corine Land Cover, [25]), the use differentiated soil overview map of Germany 1:1,000,000 (BÜK $1000 \mathrm{~N}$, [26]) as well as climate data 1981-2010 of the German Weather Service [18].

\section{Ordinating ecosystem service Habitat}

For the evaluation of the potential services of an ecosystem type class as habitats for plants and animals, the following criteria are of primary importance ([27], expanded and modified).
a. Hemeroby (degree of naturalness)
b. Compositional completeness
c. Habitat value for fauna
d. Vulnerability/need for protection
e. Recoverability/restorability/replacability of habitats
f. Maturity
g. Position within the biotope network

These criteria are defined below and assigned in Table 6 to the six ecosystem service levels 0 to 5 mentioned in the above "Linking ecosystem type classes reference states with ecosystem services" section.

\section{(a) Hemeroby}

This is to be understood as the deviation of the current ecosystem type class from the current potentially natural vegetation type (Table 6). Hemeroby is a measure of an ecosystem's ability for self-regulation.

(b) Compositional completeness

\section{Relative compositional completeness of flora and characteristic vegetation structure}

The "National Strategy on Biological Diversity" [28] aims at the conservation and development of natural and semi-natural forest communities. This requires using the degree of similarity of the species composition and vegetation structure of an ecosystem to a reference state as a criterion for classifying the biodiversity of an ecosystem type class (Table 6). The species combinations in the reference status of ecosystem types that have been quantitatively described at sites with little or no pollution around 1961 or before serve as a reference. The comparison of the potential with the current species composition and its vegetation structure is the measure for the classification of biodiversity in terms of the above-mentioned biodiversity strategy.

(c) Habitat value for fauna

The evaluation of the potential ecosystem service of an ecosystem type class as a habitat for animals is based on species groups that have more or less distinct preferences for certain ecosystem type class as (partial) habitats. A high score applies for ecosystem types with as many (partial) habitat functions as possible for as many animal groups 
as possible (Table 6). Natural wet forests have a very high habitat value for the indicator animal species. The anhydromorphic near-natural forests and semi-natural openland ecosystem types have high habitat values. Managed forests usually have an average habitat value for their indicator animal species. The habitat requirements of selected species protected under EU law is listet in Additional file 1: Table S1.

(d) Vulnerability/need for protection Ecosystem types that are designated as Flora Fauna Habitat types (Annex I FFH Directive) are of particular importance. Ecosystem types that provide habitats for protected species are of great importance. The following regulations and directives identify particularly vulnerable protected assets in terms of habitats (Table 6):

- Directive 2009 /147/EC of the European Parliament and of the Council of 30 November 2009 on the conservation of wild birds Council Directive 92/43/EEC of 21 May 1992 on the conservation of natural habitats and of wild fauna and flora (FFH Annex II and IV)Annex A VO 1332/2005 EC Species Protection Regulation (EC REG)

- Annex B VO 1332/2005 EC Species Protection Regulation (EC REG)

- Federal Species Protection Ordinance (BArtSchV) Annex 1, column 2

- Federal Species Protection Ordinance BArtSchV Annex 1, column 3

Species protected under EU law that are relevant in Germany are listet in Additional file 1: Table S1.

(e) Recoverability/restorability/replacability of habitats If, after planting/seeding/establishing an initial vegetation (trees, shrubs and/or dominant grass species, soil and water regime design), a functioning and self-regenerating ecosystem has been established within the time specified under recoverability (Table 6), the ecosystem type is deemed to have been restored.

(f) Maturity

Near-natural woods in the mature stage have the highest possible habitat potential for most animal and plant species typical for the forest ecosystem, as the native species are evolutionarily particularly well adapted to the climax woods that existed almost everywhere before the Middle Ages. The maturity of ecosystems is a non-linear process over time. A mature ecosystem is characterized by a mosaic of structures, uneven-aged mixed stands of different tree species, and diverse compositions of lower vegetation layers. Nevertheless, the term maturity is to be used here to describe a self-organising stage of wood development (Table 6).

(g) Importance within the biotope network

The importance of ecosystem type classes in the biotope network system (Table 6) will also be measured by its function as habitat or partial habitat of species with very large area requirements (e.g., griffins, large mammals, etc.).

The ordination of the habitat function for 78 ecosystem type classes is given in "Results and discussion" section. The integration of the criteria-specific evaluation took into account a ranking of the criteria which assumes that the individual criteria should not be included in a merge on an equal footing. The weighting was derived from the frequency of mention of the respective criterion as a requirement for habitat functions for the protected species relevant in Germany in Additional file 1: Table S1. Hemeroby was given first priority, and the following criteria were prioritised in the order in which they were listed. The following equation was then used to make additions to or deductions from the hemeroby score:

$$
\begin{aligned}
L= & N+((R-N) * 0.5)+((H-N) * 0.25) \\
& +((S-N) * 0.125)+((W-N) * 0.06) \\
& +((M-N) * 0.03)+((B-N) * 0.015),
\end{aligned}
$$

$L$ is the score for total habitat function; $N$ is the Hemeroby for closeness to nature; $R$ is the classification points for the relative compositional completeness of flora and characteristic vegetation structure; $H$ is the score for habitat value for fauna; $S$ is the score for the need for protection; $W$ is the score for recoverability; $M$ is the score for the maturity certificate; $B$ is the score for the position in the biotope network system.

The results of the evaluation of the individual criteria and the overall evaluation of the potential services of an ecosystem type class as habitat are listed in "Results and discussion" section, Table 21, Column 6 for the 78 ecosystem type classes.

Accordingly, ecosystem type classes with near-natural mixed forests on rare extreme sites, e.g., the moist and wet forests as well as the near-natural forests of the nutrient-poor and/or dry sites have the highest ecosystem services ordination scores. In addition to the high hemeroby score, the high protection status also contributes to this. Conifer reforests, on the other hand, usually have low scores. However, if they correspond to the potentially natu- 
ral vegetation in terms of tree species composition and differ from it only in the over-representation of the main needle tree species and in the absence of secondary tree species, they may also reach medium scores.

\section{Ordinating ecosystem service carbon storage}

Carbon $(\mathrm{C})$ is fixed and thus stored in the living biomass and in the soil organic matter. However, the proportion of carbon in living biomass is about one third compared to the stock in the soil [29]. In the following, therefore, the carbon storage function in the soil will be considered in simplified terms. A part of the $\mathrm{C}$ stock from dead biomass is in the (not yet) decomposed leaf/needle litter in the humus layer (in the German forest soils approx. 18\% on average-[30]. The largest C-reserve (59\%-ibid.) is present in the mineral soil layer up to $30 \mathrm{~cm}$. Here, the humic substances are integrated into organo-mineral complexes (e.g., clay-humus complexes) that are stable in the long term.

The following criteria are of particular importance for ordinating the service potentials of the ecosystem type classes for $C$ storage [30]:
a. Clay content
b. Mass of litter and harvest residues
c. Decomposability of litter and harvest residues
d. Annual mean temperature and annual precipitation total
e. Soil water content
f. $\mathrm{pH}$ value.

The ordination of the ecosystem service $C$ storage was performed according to Table 6 . The ecosystem service ordination was carried out by assigning the levels ( 0 to 5: very low to very good) to a classified expression of the characteristics previously mentioned under (a) to (f).

(a) Clay content

Since the $\mathrm{C}$ stock in the organic layer averages only about one fifth of the $\mathrm{C}$ stock in the mineral soil, the clay content is significantly positively correlated with the $\mathrm{C}$ stock for the soil profiles [30]. However, clay content is also a criterion which, among other factors, influences soil fertility (and thus the amount of needle and leaf litter), soil water content, effective cation exchange capacity and $\mathrm{pH}$ (and thus the activity of humus decomposers). The clay content is the strongest factor influencing carbon storage [30-32].

(b) Mass of litter and crop residues

Carbon is predominantly stored in soil in organic form. It results in part from non-mineralised com- ponents, in particular from undecomposed or partially decomposed components of the plant litter and harvest residues (leaves, needles, bark, branches, coarse roots, fine roots). In forests, the litter mass is dependent on soil fertility, but also on the main tree species, with some stock-forming tree species preferring soils to a certain nutritional level and thus acting as indicators of soil fertility.

(c) Decomposability of litter and harvest residues The decomposability of plant residues depends (also) on the chemical composition of the litter. A low $\mathrm{C} / \mathrm{N}$ ratio and a high $\mathrm{pH}$ value in the fresh litter promote rapid degradation. A well studied criterion for decomposability is the decomposition time of the litter and harvest residues [33].

(d) Soil water content

A good water supply combined with a good oxygen supply promotes the activity of the decomposors and thus the formation of stable clay-humus complexes in the mineral soil. Drought, on the other hand, leads to a reduction in activity. But anaerobic conditions in the soil also inhibit the mineralisation of the litter. Although degradation also takes place in the case of oxygen deficiency, since methanogenic microorganisms, for example, take over the mineralization, the degradation process under anaerobic conditions is much slower and usually incomplete [34]. The inhibition of degradation in water-saturated soils can take on such proportions that peat layers are formed from little decomposed litter, which in turn accumulate a high stock of organically bound carbon [22].

(e) Annual mean temperature and annual precipitation total

While the carbon stock in humus increases at high water contents and lower annual average temperatures, the carbon accumulation rate in the mineral soil, where the highest proportion of the $C$ stock is located, decreases at high water contents and low temperatures. The rate of mineralization of organic matter and the subsequent formation of stable organo-mineral complexes is controlled, among other things, by temperature and precipitation. The biological activity of mineralising soil organisms increases with increasing soil temperature. The soil temperature in the biologically active topsoil is rarely measured and depends on the annual average air temperature (Table 6). The activity of humusdecomposing soil organisms is inhibited by anaerobic conditions in the soil. High levels of precipitation lead to anaerobic conditions more frequently and for longer periods of time [33]. 
Table 7 Rules for integrating the criteria-specific classifications of carbon storage potentials

\begin{tabular}{|c|c|c|c|}
\hline Prio-rity & Subtotal factor 1 & Criterion & Merger to subtotals \\
\hline 1 & Clay content $(T)$ & & $T=T$ \\
\hline \multirow[t]{2}{*}{2} & \multirow[t]{2}{*}{ Spread mass production (S) } & Max. spreading mass productivity $\left(S_{\text {pot }}\right)$ & \multirow[t]{2}{*}{$S=\left(\left(E P_{\text {geo-prof }}-1\right) /(5-1)\right) * S_{\text {pot }}$} \\
\hline & & Yield potential of the soil profile (EPgeo-prof) & \\
\hline \multirow[t]{4}{*}{3} & \multirow[t]{4}{*}{ Influence on destructor activity (D) } & $\mathrm{pH}\left(\mathrm{H}_{2} \mathrm{O}\right)$ value $(\mathrm{pH})$ & \multirow[t]{4}{*}{$D=(\mathrm{pH}+J+W+Z) / 4$} \\
\hline & & $\begin{array}{l}\text { Climate [annual precipitation total/annual mean } \\
\text { temperature }(J) \text { ] }\end{array}$ & \\
\hline & & Soil water content $(W)$ & \\
\hline & & Decomposition time ( $Z$ ) & \\
\hline
\end{tabular}

(f) $\mathrm{pH}\left(\mathrm{H}_{2} \mathrm{O}\right)$-value In different $\mathrm{pH}$-value ranges, the organism community in the soil is composed of different species or species groups, which develop different decomposition intensities. At a $\mathrm{pH}\left(\mathrm{H}_{2} \mathrm{O}\right)$ value $<4.2$, for example, earthworms and bristle worms are no longer viable. In addition to humus decomposition, they are also responsible for combining humic and mineral substances and transporting them from the overburden to the upper mineral soil layer. On the other hand, the $\mathrm{pH}$ value is usually highly correlated with the base saturation, so that a high $\mathrm{pH}$ value is also an indicator of a good nutrient cation supply for the humus destruents. The lower the $\mathrm{pH}$, the lower the activity of the destructants [35]. However, a high activity of the destruents is the prerequisite for the formation of organo-mineral complexes in the mineral soil, where the largest $C$ content is stored.

When the criteria-specific ordination scores were integraded, a ranking of the criteria was taken into account which assumes that the individual criteria should not be equally weighted. The criterion of clay content was given first priority, followed by the production of litter mass. The production of litter mass only results from the plant physiologically possible maximum litter mass production, relativised on the basis of the yield potential of the soil. The third priority is given to the influencing factors on the decomposition activity of the humus destructors. The influencing factors $\mathrm{pH}$ value, climate, volumetric water content in the soil and the decomposition time are equally weighted and combined to form an arithmetic mean value (Table 7). To classify the clay content, additions or deductions were made according to the following equation:

$$
K=T+((S-T) * 0.5)+((D-T) * 0.25),
$$

with $K$ is the total classification of the carbon storage function; $T$ is the total content classification; $S$ is the classification of spreading mass production; $D$ is the classification of the influence on destructor activity.

The weighting of the criteria for the assessment of carbon storage capacity follows the analysis and evaluation of the soil condition survey in Germany 2006-2008 [30]. The results of the ordination of the individual criteria and the overall ordination of the ecosystem service $C$ storage are listed in "Results and discussion" section, Table 21, Column 8 for the 78 ecosystem type classes. The following conclusions can, therefore, be drawn: the highest value groups in ecosystem type classes are rich beech forests (e.g., "Central European to subcontinental, moderately dry to fresh, nutrient-rich hornbeambeech forest", "sub-oceanic, moderately dry to fresh, nutrient-rich beech forest", "sub-oceanic, moist, nutrient-rich beech forest").

Pine forests and forests, which are mostly restricted to dry or humid, nutrient-poor locations, have low carbon storage capacities. Very low potential for storing carbon in soil is assessed to the ecosystem type classes "Central European to subcontinental, dry, moderately nutritious pine forest" and "Central European to subcontinental, dry, rather poor pine forest" occur particularly frequently. Among the 25 ecosystem type classes with a low $C$ storage function are current near-natural forest ecosystems, such as the ecosystem type class "sub-oceanic, moderately dry to fresh, rather poor beech forest". However, many ecosystem type classes also have little potential for $\mathrm{C}$ storage. This ecosystem type classes includes, for example, spruce forests such as the "sub-oceanic, moderately dry to fresh, moderately nutritious spruce forest" or the "sub-oceanic, moderately dry to fresh, moderately nutritious pine forest", which are very dominant in terms of area. Furthermore, 17 ecosystem type classes have medium potential for carbon storage. 
Table 8 Intervals of net primary production (imber stage) of dominant and sub-dominant species. Sources: Bauer [37], Böckmann [38], Erteld [39], Jüttner [40], Knapp [41], Schober [42] in Schober [43, 44], Schwappach [45] in Schober [43], Wiedemann [46] in Schober [43], Wiedemann [47] in Schober [43], Wimmenauer [48]

\begin{tabular}{|c|c|c|c|}
\hline \multirow[t]{3}{*}{ Tree species } & \multicolumn{2}{|c|}{ Average annual growth rates after 100 years (DGZ 100) } & \multirow[t]{3}{*}{ Score } \\
\hline & $\begin{array}{l}\text { Net primary productivity of yield class I for } \\
\text { logs with bark }\end{array}$ & $\begin{array}{l}\text { Net primary productivity of the worst yield class } \\
\text { for logs with bark }\end{array}$ & \\
\hline & $E_{\max (\text { Phyto) }}\left(\mathrm{t}\right.$ dry mass ha $\left.{ }^{-1} \mathrm{a}^{-1}\right)$ & $E_{\min (\text { Phyto) }}\left(\right.$ t dry mass ha $\left.{ }^{-1} \mathrm{a}^{-1}\right)$ & \\
\hline Scots pine & 3.5 & 1.4 & 3 \\
\hline Spruce & 4.9 & 3.2 & 5 \\
\hline Mountain and Black pine & 0.7 & 0.7 & 1 \\
\hline Silver fir & 3.5 & 3 & 3 \\
\hline European larch & 2.5 & 2 & 2 \\
\hline Beech & 4.9 & 2.4 & 5 \\
\hline Pedunculate and sessile oak & 4 & 1.4 & 4 \\
\hline Alder & 4.3 & 2.5 & 4 \\
\hline Birch, all species & 2.8 & 2.1 & 2 \\
\hline Willows, all species & 2.3 & 1.6 & 2 \\
\hline Elm, all species & 4.8 & 3 & 4 \\
\hline Ash & 3.7 & 2.5 & 4 \\
\hline Mountain ash & 2.1 & 1.6 & 2 \\
\hline Lime tree, all species & 5.2 & 3 & 5 \\
\hline Maple, all species & 3.5 & 2.5 & 3 \\
\hline Poplars, aspen, all species & 4.5 & 1.1 & 4 \\
\hline
\end{tabular}

\section{Ordinating ecosystem service aboveground biomass primary} production

The following criteria were of particular importance for ordinating the service potentials of the ecosystem type classes for biomass primary production: plant physiological net primary productivity, specific soil fertility and climate influence on fertility. The following method serves to link the reference state of biomass productivity to the ecosystem type classes.

(a) Plant physiological net primary production The classification of plant species-specific net primary productivity for the reference status of ecosystem type classes shall be based on the potential of species at sites in the sustainable ecological balance of nutrient, water and energy balance. For this reason, yield tables and yield statistics which were collected at sites which represent a more or less harmonious equilibrium of the site factors or which represented this equilibrium at the time of the respective survey, i.e., surveys in particular from the period before 1960 were to be evaluated for the estimation, in particular, for those sites which represent a more or less harmonious equilibrium of the site factors. The basis for the site-type-specific estimation of the potential net primary productivity of forests are yield tables of the current growth of tree species. Over 100 years, the average annual growth for yield class I and the worst yield class of the tree species were determined from the yield tables. The fixed measurement increments (DGZ 100) determined in this way are converted into weight measurement increments with the aid of the tree speciesspecific wood and bark density [36]. It is assumed that the bark will be removed away from the stock, as is common practice at present. The classification of the tree species-specific net primary productivity is carried out with classification points from 0 to 5 , whereby 0 is not assigned, since each tree species and each soil has a net primary productivity (Table 8).

(b) Determination of soil-specific net primary productivity

The method described below serves to concretise a discrete soil-typical value within the vegetationtype-specific range of net primary productivity (Table 8) taking into account the different soil properties. This requires first of all the best possible estimation of soil fertility as a function of the soil texture of the horizons of a rooted profile. The criteria were classified as follows. 
Table 9 Influence of plant-available adhesive water on the formation of soil-specific yield potential

\begin{tabular}{ll}
\hline Proportion of plant-available adhesive water (vol\%) & Scores \\
\hline$>22$ & 5 \\
20 to 22 & 4 \\
17 to $<20$ & 3 \\
13 to $<17$ & 2 \\
$<13$ & 1 \\
\hline
\end{tabular}

Table 10 Influence of the proportion of rootable air-filled pores on the formation of soil-specific yield potential

\begin{tabular}{ll}
\hline Proportion of rootable air-filled pores ( vol\%) & Scores \\
\hline$>15$ & 5 \\
12 to 15 & 4 \\
9 to $<12$ & 3 \\
5 to $<9$ & 2 \\
$<5$ & 1
\end{tabular}

Soil texture and pedogenesis The nomenclature of soil texture classes was based on the German Soil Mapping Guide [20]. The criteria of thoroughness could be inferred indirectly from the formation and directly from the groundwater distance. Therefore, the soil texture classes were further subdivided according to pedogenesis (diluvial, alluvial, weathered soils).

Pores with dead water, plant-available adhesive water and air The volume fractions and diameters of waterand air-filled pores as well as the suction tension of the different soil types were taken from Amberger [49, p. 76].

The proportion of plant-available adhesive water (=usable field capacity) at the various storage densities is highest on average at $26 \mathrm{vol} \%$ in silt and sandy silt and lowest at approximately $10 \mathrm{vol} \%$ in pure sands. The classification is given in Table 9.

The proportion of pores in rootable air-filled pores is highest in pure sands at $36 \mathrm{vol} \%$ and lowest in clays at 4 vol\% (Table 10). With a ratio of the pores with available adhesive water to air-filled root-through pores of $1: 1$, optimum plant growth is given [49].

Complementary to the air void components are the components of water-filled pores in which the water tension due to adhesion is greater than the suction tension of the plant roots $(\mathrm{pF}>4.2=$ dead water). The proportion of very small pores with high adhesive forces is particularly high in clays (42 vol\%) and zero in coarse sands (Table 11).

In soils with a high proportion of medium and fine pores and a low proportion of coarse pores (silt, clays),
Table 11 Influence of the proportion of water-filled pores on the formation of soil-specific yield potential

\begin{tabular}{ll}
\hline Pore fraction with dead water (vol\%) & Scores \\
\hline$<5$ & 5 \\
5 to $<10$ & 4 \\
10 to $<15$ & 3 \\
15 to 25 & 2 \\
$>25$ & 1 \\
\hline
\end{tabular}

Table 12 Influence of dead water and air void content on the formation of soil-specific yield potential

\begin{tabular}{ll}
\hline Sum of dead water and air void fraction ( vol\%) & Scores \\
\hline$<20$ & 5 \\
20 to $<25$ & 4 \\
25 to $<30$ & 3 \\
30 to 35 & 2 \\
$>35$ & 1 \\
\hline
\end{tabular}

adhesive water leads to a lack of air and to waterlogging caused by adhesive water. The waterlogging hazard can, therefore, also be derived from the proportion of dead water pores $(\mathrm{pF}>4.2)$.

Risk of dehydration The supply of plants with water in anhydromorphic or drained soils depends directly on the usable field capacity. While with large soil pores (e.g., in soils consisting predominantly of sand) the adhesion and adsorption forces are not sufficient to form a water column in the pores, i.e., the precipitation water flows predominantly as seepage water into the deeper soil layers and is no longer available to the plants, the very high adhesive tension against water in the narrow pores, e.g., from silt and clay, also represents an irretrievable water loss for the plants (permanent wilt point at $\mathrm{pF}>4.2$ ). Both soil types are, therefore, particularly susceptible to drying out. The combination of the dead water pore fraction and that of the air void fraction results in the classification of the risk of drying out (Table 12).

Groundwater influence This criterion indicates the influence of groundwater on the plant growth of non-wet dependent plant species. It is true that if the groundwater distance is smaller than the potential root penetration depth, plant growth is restricted due to a lack of air in the soil pores. Direct groundwater influence (ground moisture) can, therefore, have an unfavourable influence on plant growth. A favourable influence is exerted by a groundwater field distance at which the soil species-spe- 


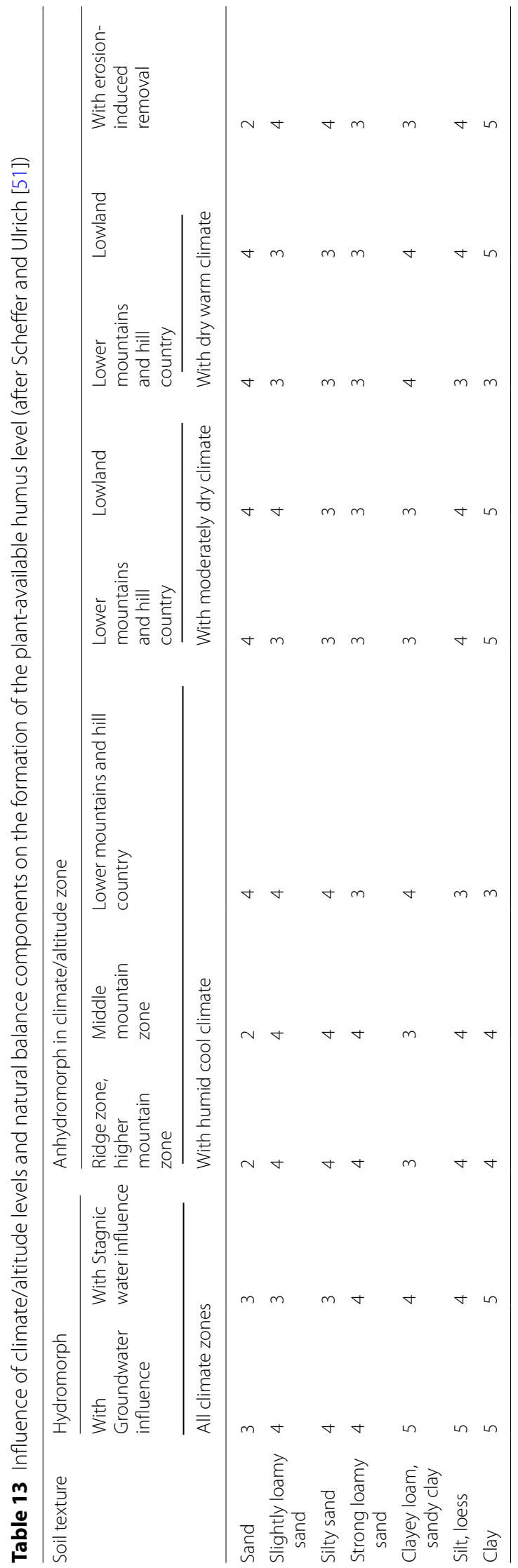


cific capillary ascending force (closed capillary chamber) reaches the effective root penetration depth and thus ensures sufficient soil moisture at all times. If the closed capillary space above the groundwater level generally never reaches the effective root penetration depth, the non-existent influence of the groundwater is classified as "very unfavourable" in this classification. However, it also depends on the way in which the soil is formed. It can, therefore, be simply assumed that diluvial, loess and weathered soils are not influenced by groundwater, whereas alluvial and coastal soils are generally close to groundwater, i.e., the effective root penetration depth of the capillary space is achieved (Table 13).

Humus content The content of organic matter in the mineral topsoil is essentially dependent on climatic influences, annual mean temperature and precipitation as well as on the influence of bases and nitrogen. The organic matter of the soil is of enormous importance, e.g., for water storage capacity, base sorption power and thus for nutrient storage and mobility. For this reason, the humus level was used as a criterion for classifying the nutrient balance (Table 13).

Cation exchange capacity The cation exchange capacity represents the potential amount of exchangeable cations necessary for plant nutrition (calcium, magnesium, potassium, ammonium ions) and other ions (e.g., hydrogen and aluminium ions) in the soil complex. The type and proportions of clay minerals and organic substances determine the cation exchange capacity. The cation exchange capacity of the clay minerals is essentially permanent. The soil species-specific potential cation exchange capacities are highest for high clay and silt contents in the upper horizons ( $30 \mathrm{cmolc} / \mathrm{kg}$ for loamy, siltigen and pure clays), lowest $(2 \mathrm{cmolc} / \mathrm{kg})$ for breeze and pure sands [20] (Table 14).

Rootable depth Information on rootable depth (shallow, medium or deep) can be derived indirectly from the formation and directly from the groundwater distance. Therefore, the soil types were further subdivided into genesis types (diluvial, alluvial, weathered soils). The influence of rootable depth on plant growth was classified according to Table 15.

Tendency to solidify This criterion indicates the degree of internal cohesion of horizons or layers as a result of the action of cementing substances. The higher the degree of cementation of the soil particles (e.g., due to deposits), the greater the tendency to solidify. According to Hennings [50], particularly non-cohesive soils with low humus content tend to form putty structures with a high degree of consolidation. It shall be classified in accordance with Table 16.

To determine the soil-specific net primary productivity, the individual parameters are determined according to soil texture (Table 17). If a soil profile is composed of horizons of different soil textures, the mean value of the classification points is formed over the profile $\left(\mathrm{EP}_{\text {(geo-prof })}\right)$, i.e., over all horizons of the root area, taking into account the respective thickness of each horizon (depth-weighted averaging).

(c) Determination of climate-specific net primary productivity

The length of the vegetation period is a highly significant climate-ecological influencing factor. The longer the vegetation period in the year (number of days in the year with an average air temperature of $\geq 10{ }^{\circ} \mathrm{C}$ ), the greater the net primary production. Good to very good growth rates are promoted by vegetation periods ranging from 100 days (medium montane sites) to 200 days (planar lowland sites), while in high montane and alpine regions (60-100 days) net primary production falls significantly below soil-specific net primary productivity. Therefore, the soil-specific net primary productivity is related and classified to the growing season according to Table 18. Rainfall also influences net primary productivity (Table 19).

(d) Consolidation of the criteria-specific ordination for the overall classification of the service potentials of biomass primary production

The merging of the criteria-specific classifications took into account a ranking of the criteria which assumes that the individual criteria should not be included in a merge on an equal footing. The criterion of plant physiological net primary production (annual above-ground timber growth) was given first priority, followed by soil-water balance, nutrient balance, soil structure and climate influence (Table 20).

The ordination score for net plant physiological primary production was then specified according to the following formula:

$$
\begin{aligned}
\mathrm{NPP}= & P+((W-P) * 0.5)+((N-P) * 0.25) \\
& +((G-P) * 0.125)+((K-P) * 0.06)
\end{aligned}
$$

NPP is the ordination score for total biomass primary productivity; $P$ is the ordination score for net plant physiological primary production (annual above-ground timber growth); $W$ is the ordination score soil water balance; $N$ is the ordination score for nutrient balance; $G$ is the ordination score for the soil structure; $K$ is the ordination score for the climate.

The weighting according to this formula was based on the "Soil Quality Rating" (SQR) [52]. However, this only applies to Germany and possibly to Central Europe. In 
Table 14 Influence of cation exchange capacity on the formation of soil-specific yield potential

\begin{tabular}{ll}
\hline Cation exchange capacity $\left(\mathrm{cmol}_{\mathrm{C}} / \mathrm{kg}\right)$ & Scores \\
\hline$>20$ & 5 \\
15 to 20 & 4 \\
10 to $<15$ & 3 \\
5 to $<10$ & 2 \\
$<5$ & 1 \\
\hline
\end{tabular}

Table 15 Influence of the rootable depth on the formation of the soil-specific yield potential

\begin{tabular}{ll}
\hline Rootable depth & Scores \\
\hline Deep & 5 \\
Medium to deep & 4 \\
Medium & 3 \\
Medium to shallow & 2 \\
Shallow & 1
\end{tabular}

Table 16 Influence of consolidation tendency on the formation of soil-specific yield potential

\begin{tabular}{ll}
\hline Soil type & Scores \\
\hline Soils without podsolation tendency & 5 \\
Podzoluvisol & 4 \\
Arenosol & 3 \\
Cambic podzol & 2 \\
Sandy podzol & 1 \\
\hline
\end{tabular}

other European regions, where climatic factors limit primary production to a greater extent, the weighting must be adjusted accordingly. The results of the evaluation of the individual criteria and the overall ordination of the service potential for biomass primary production (here classified on the basis of the annual tree growth on average over 100 years) are listed in "Results and discussion" section, Table 21, Column 12 for the 78 ecosystem type classes. The following conclusions can, therefore, be drawn: the classes with high and very high service potential score are 'sub-oceanic, moderately dry to fresh, moderately nutritious beech forest', 'sub-oceanic, moderately dry to fresh, moderately nutritious spruce forest' and 'sub-oceanic, moderately dry to fresh, nutritious beech forest'. This potential is concentrated mainly in the low mountain ranges of southern and western Germany. A low or very low potential for biomass primary production was identified for the ecosystem type class "Central European to subcontinental, dry, rather poor pine forest".

\section{Results and discussion}

As a result of assigning forest ecosystem types (presented by Jenssen et al. [1]) to the presented classes of abiotic site parameters and considering different graduation of ecosystem services, 78 ecosystem type classes were created.

The forest ecosystem types according to Jenssen et al. [1] contain, among other things, information on the main tree species of the currently near-natural ecosystem types. The ecosystem type classification of the currently near-natural ecosystem types according to Jenssen et al. [1] also contains forest ecosystems that fulfill the condition of indicating a self-regulating structure of natural components in a state of ecosystem equilibrium, but which, due to the dominance and/or uniformity of one or a few tree species as a result of management, cannot fulfill certain functions even in the state of ecosystem equilibrium of the abiotic natural components to the same extent as a near-natural forest of uneven age on the same site could. However, since these forest ecosystems are also current near-natural ecosystem types, the reference condition information is used to these ecosystem types to derive maximum possible forest performance potentials, just as is done for the near-natural forest ecosystem types.

The results from the ecosystem type classes as well as the ordination according to ecosystem service potentials can be presented in tabular form. Table 21 is structured as follows: the columns represent the examined ecosystems services, which are structured according to the CICES ("Background" section). The lines show the summarized and renamed ecosystem type classes. The ecosystem services potentials are the medians of the ecosystem type classes from all ecosystem services scores of ecosystem type classes. In the tables dark green areas show high potentials for the provision of the corresponding ecosystem service. In contrast, the pink and light green areas point to lower potential. The term "wood" in Table 21 is applied to near-natural forests, while "forest" means non-natural forests.

The provision of ecosystem services is based on complex interactions of biotic and abiotic ecosystem components, which can be measured and used for a rule-based ordination of the service potentials. The comprehensive methodology presented here operationalises the MAES working group's guidelines quantitatively and in a transparent, rule-based manner. The MAES classification framework for integrative ecosystem assessments comprises the data-driven mapping of ecosystems types as well as the ordination of deviances of current (1991-2010) and future (2011-2070) conditions from a historical reference (1960-1990) and of rulebase-related ecosystem services. The rule-based ordination of the 


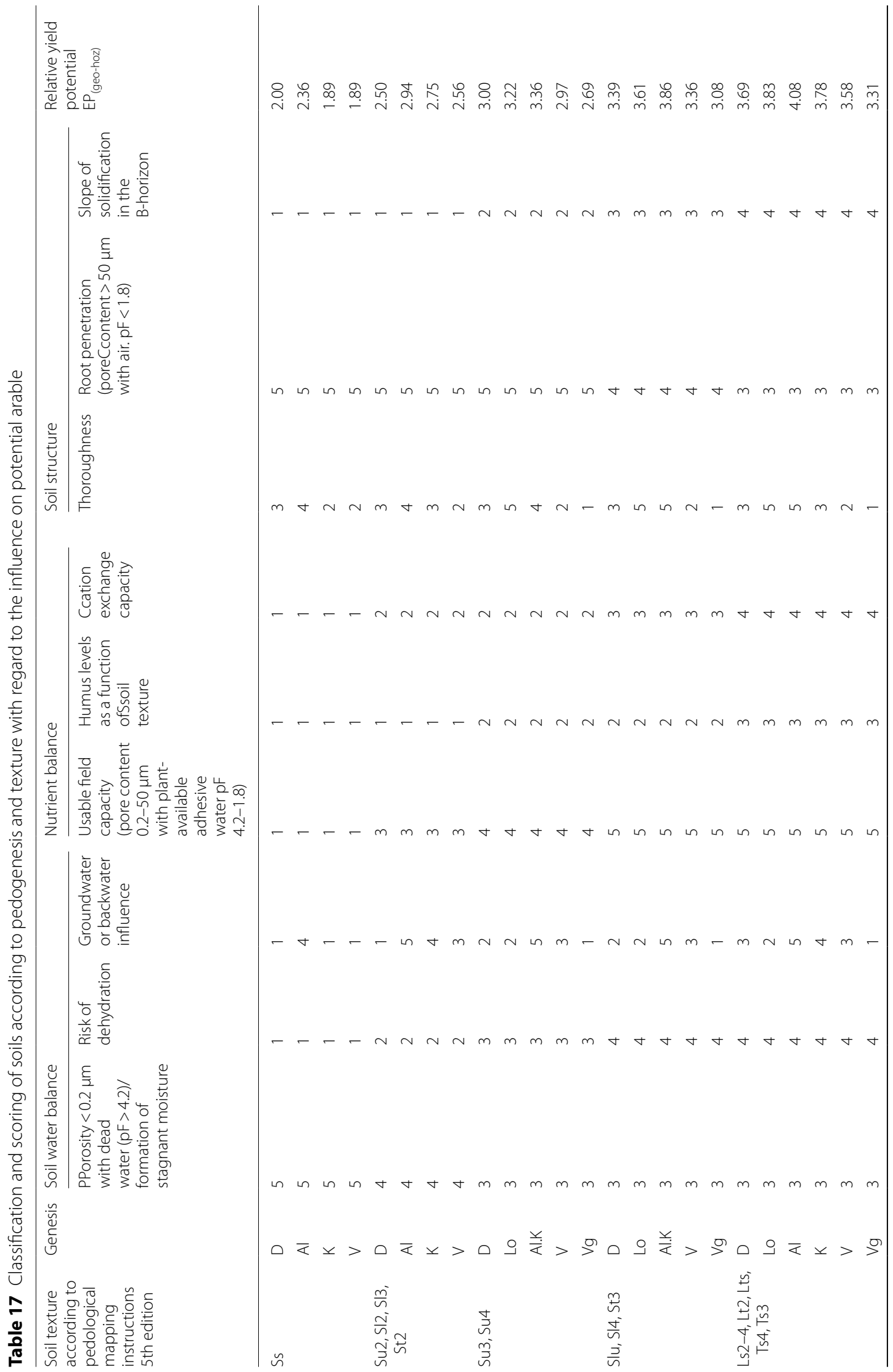




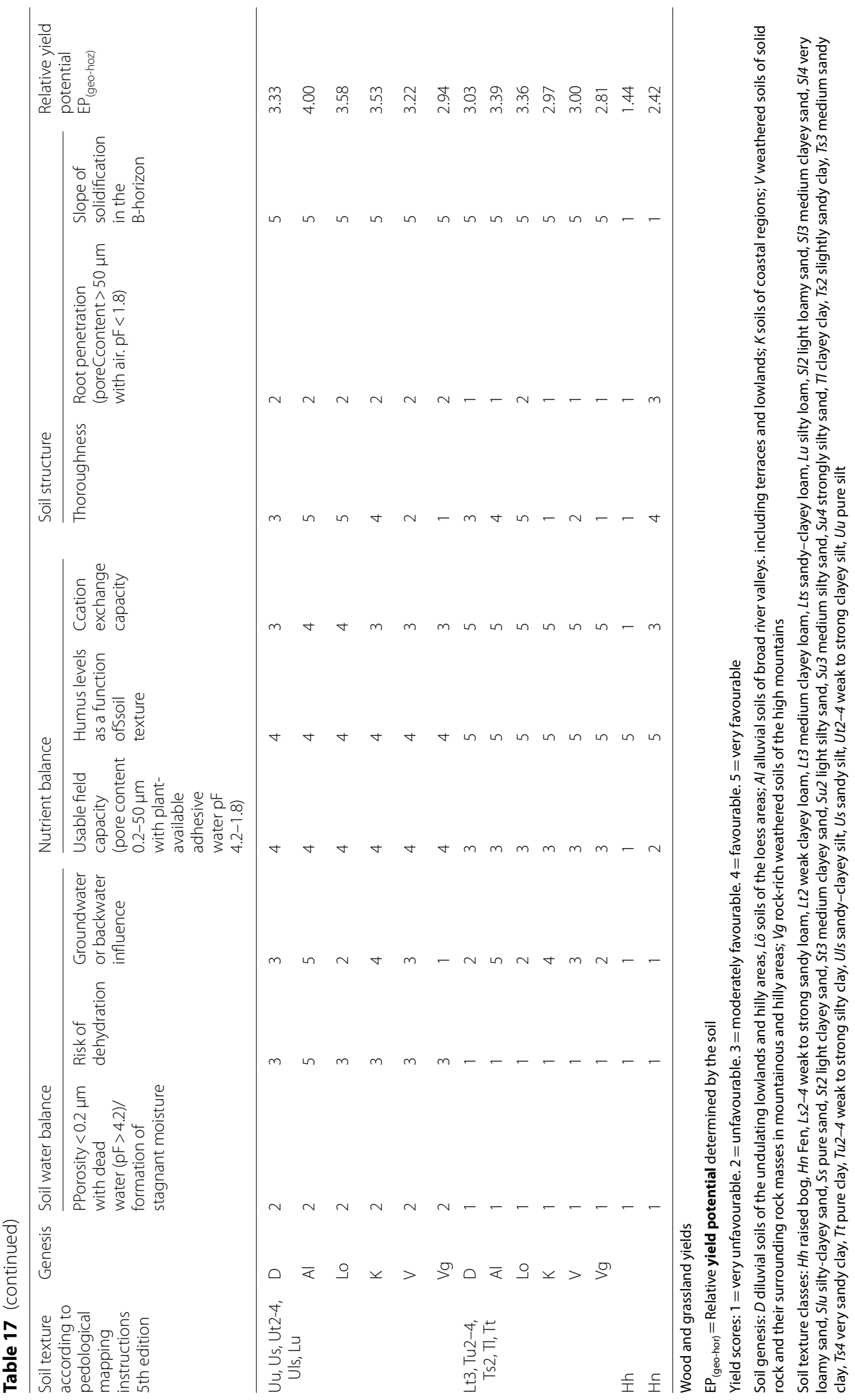


Table 18 Vegetation period length as a function of annual mean temperature as a factor influencing net primary productivity

\begin{tabular}{lll}
\hline $\begin{array}{l}\text { Classification of annual } \\
\text { average temperature }\end{array}$ & $\begin{array}{l}\text { Classification of vegetation } \\
\text { period } d<10^{\circ} \mathrm{CTMT}^{-1}\end{array}$ & Scores \\
\hline-4 bis $8{ }^{\circ} \mathrm{C}$ & $65-135$ & 1 \\
4.7 bis 11.1 & $120-175$ & 3 \\
5.5 bis 11.1 & $145-175$ & 4 \\
8.1 bis 12 & $165-190$ & 5 \\
\hline
\end{tabular}

Table 19 Annual rainfall as a factor influencing net primary productivity

\begin{tabular}{ll}
\hline Classification of the annual precipitation total & Scores \\
\hline 1065 to $2710 \mathrm{~mm}$ & 5 \\
745 to $1291 \mathrm{~mm}$ & 4 \\
514 to $854 \mathrm{~mm}$ & 3 \\
380 to $632 \mathrm{~mm}$ & 2 \\
$<400 \mathrm{~mm}$ & 1 \\
\hline
\end{tabular}

This requires a methodology that is transparent enough to be applied across the EU and/or in individual Member States. Methodological transparency allows reproducible and objective, i.e., operator-independent results. Therefore, a complex rule-based quantitative methodology was developed and presented in this article. The methodology is used to investigate the relationship between forest ecosystem conditions and services at the national level, using Germany as an example. It enables the analysis of ecosystem condition and, based on this, and estimation of how the potential of selected forest ecosystem services might change over time under the influence of climate change and atmospheric $\mathrm{N}$ deposition. The methodology presented is fully replicable, in contrast to previously published approaches. The present study suggests that the ordination approach should be complemented by other ecosystem services and extended across Europe. To this end, the following research is recommended. The study at hand suggest the recommendation to supplement the ordination approach with further ecosystem services and to extend it Europe-wide. In conclusion, the following research is recommended.

Table 20 Rules for merging the criteria-specific ordination for the overall classification of biomass productivity (annual increase in tree wood mass)

\begin{tabular}{|c|c|c|c|}
\hline Priority & Subtotal factor & Criterion & Merger to subtotals \\
\hline 1 & \multicolumn{2}{|c|}{ Plant physiological net primary production (annual above-ground tree growth) (P) } & $P=P$ \\
\hline \multirow[t]{4}{*}{2} & Soil water balance $(W)$ & Usable field capacity (nFK) & $W=(\mathrm{nFK}+T+A+\mathrm{GS}) / 4$ \\
\hline & & Porosity with dead water (waterlogging tendency) $(T)$ & \\
\hline & & Drying hazard $(A)$ & \\
\hline & & Groundwater and backwater influence (GS) & \\
\hline \multirow[t]{3}{*}{3} & Nutrient balance $(N)$ & Cation exchange capacity $(\mathrm{Ae})$ & $N=(\mathrm{Ae}+\mathrm{nFK}+H) / 3$ \\
\hline & & Usable field capacity (nFK) & \\
\hline & & Humus mirror $(H)$ & \\
\hline \multirow[t]{3}{*}{4} & Soil structure $(G)$ & Thoroughness $(\ddot{U})$ & $G=(\ddot{U}+D+F) / 3$ \\
\hline & & Rootability $(D)$ & \\
\hline & & Tendency of solidification $(F)$ & \\
\hline \multirow[t]{2}{*}{5} & Climate $(K)$ & Length of vegetation period (VZ) & $K=(V Z+P P) / 2$ \\
\hline & & Annual precipitation (PP) & \\
\hline
\end{tabular}

three ecosystem services (biomass primary production, carbon storage function and habitat function) investigated in depth on the basis of quantitative indicators in this investigation is unique in the EU.

\section{Conclusions}

As the condition of ecosystems influences their services to humans, it is the objective of the European Union to assess and map the condition of ecosystems and their services at the Union and Member State level to implement conservation or protection measures where appropriate.
A: Supplementing the classification of potentially natural forest ecosystem types with those to be expected in the course of climate change in Germany.

The list of potentially natural ecosystem types is supplemented by adding further forest ecosystem types with their reference statuses for soil chemical, climate ecological and floristic indicators from climate regions outside Germany, which will reach an increasing livelihood with further global warming in Germany. The BERN database [53, 54] contains 
Table 21 Scoring potential ecosystem services for ecosystem types covering Germany

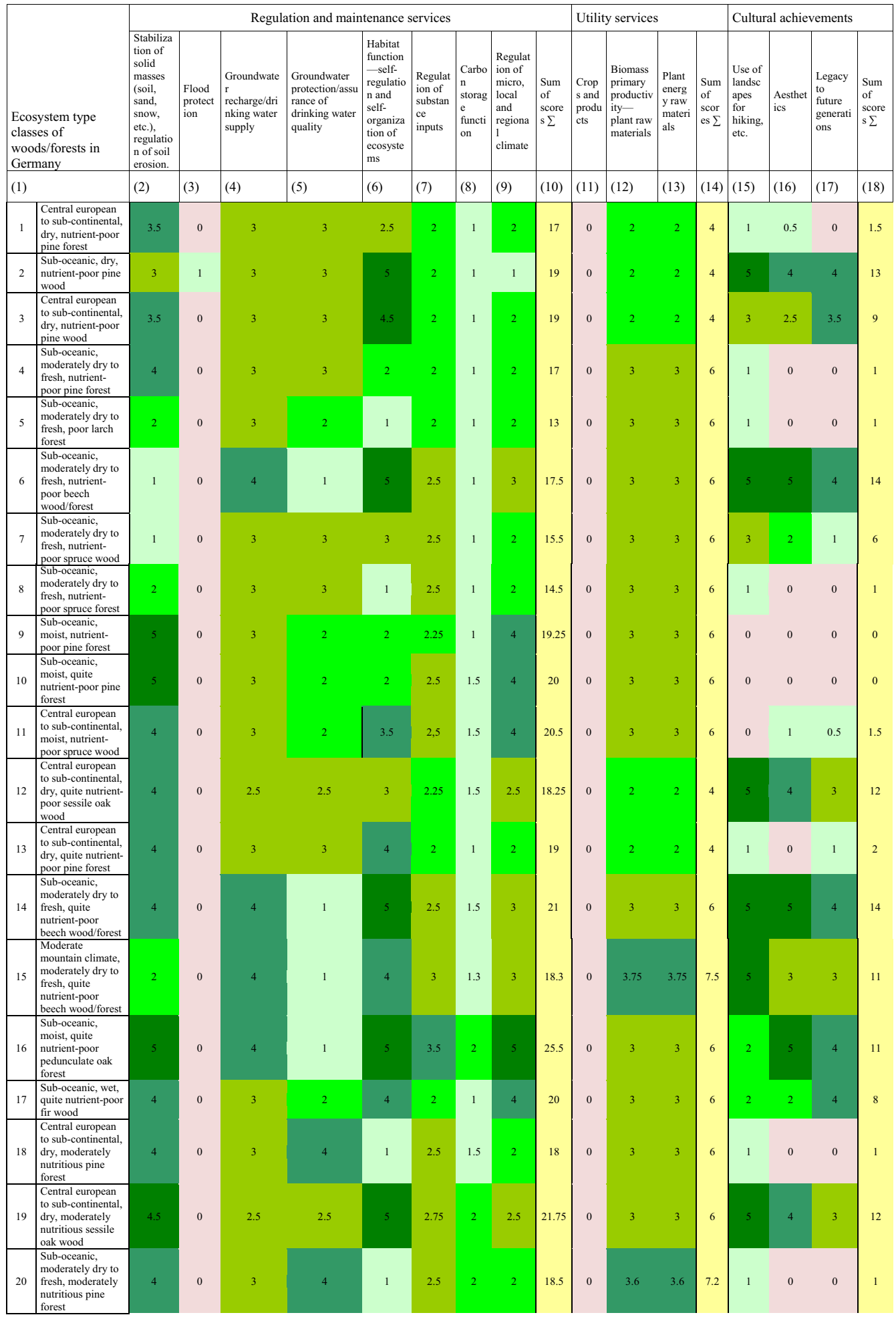


Table 21 (continued)

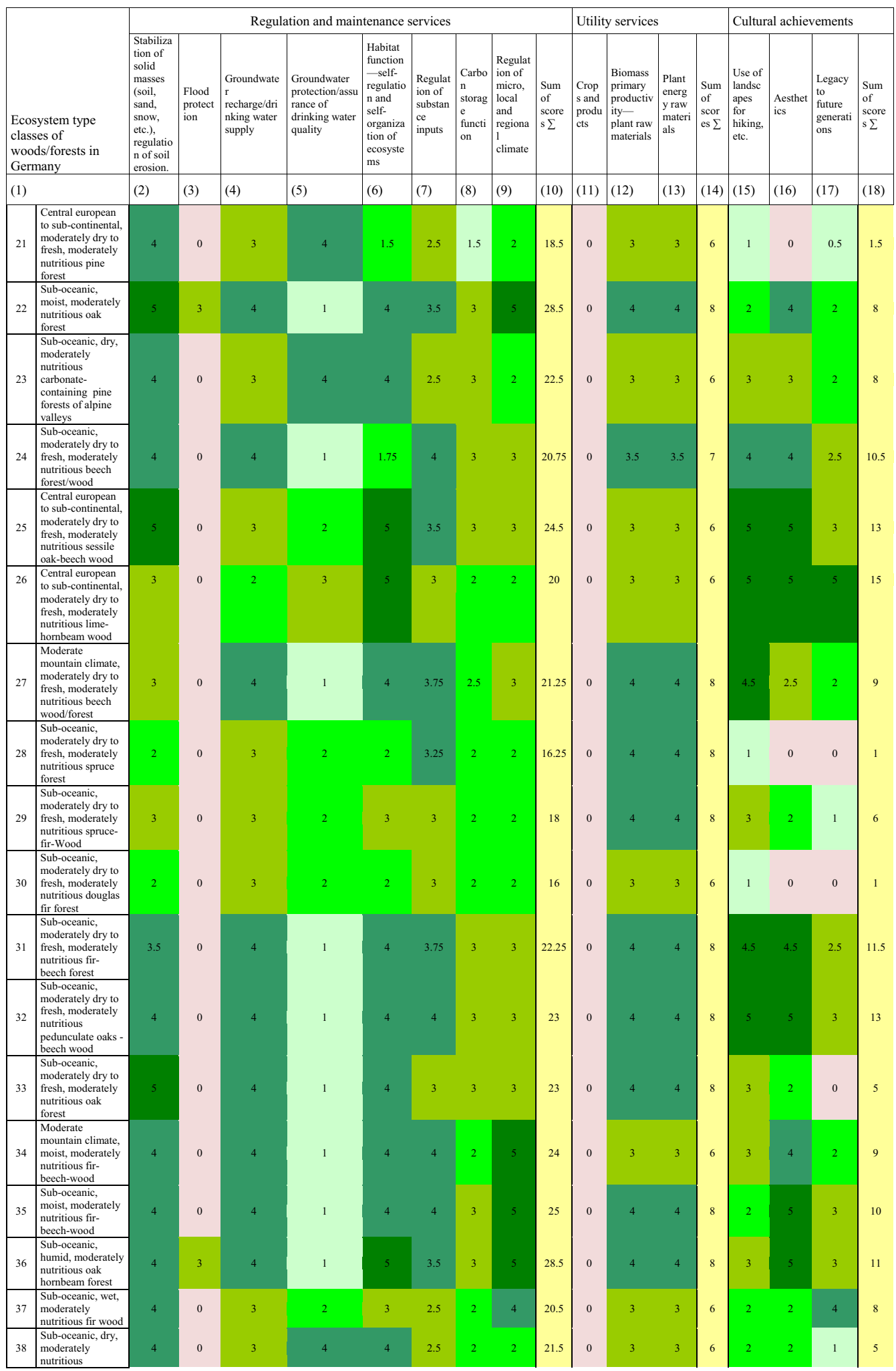


Table 21 (continued)

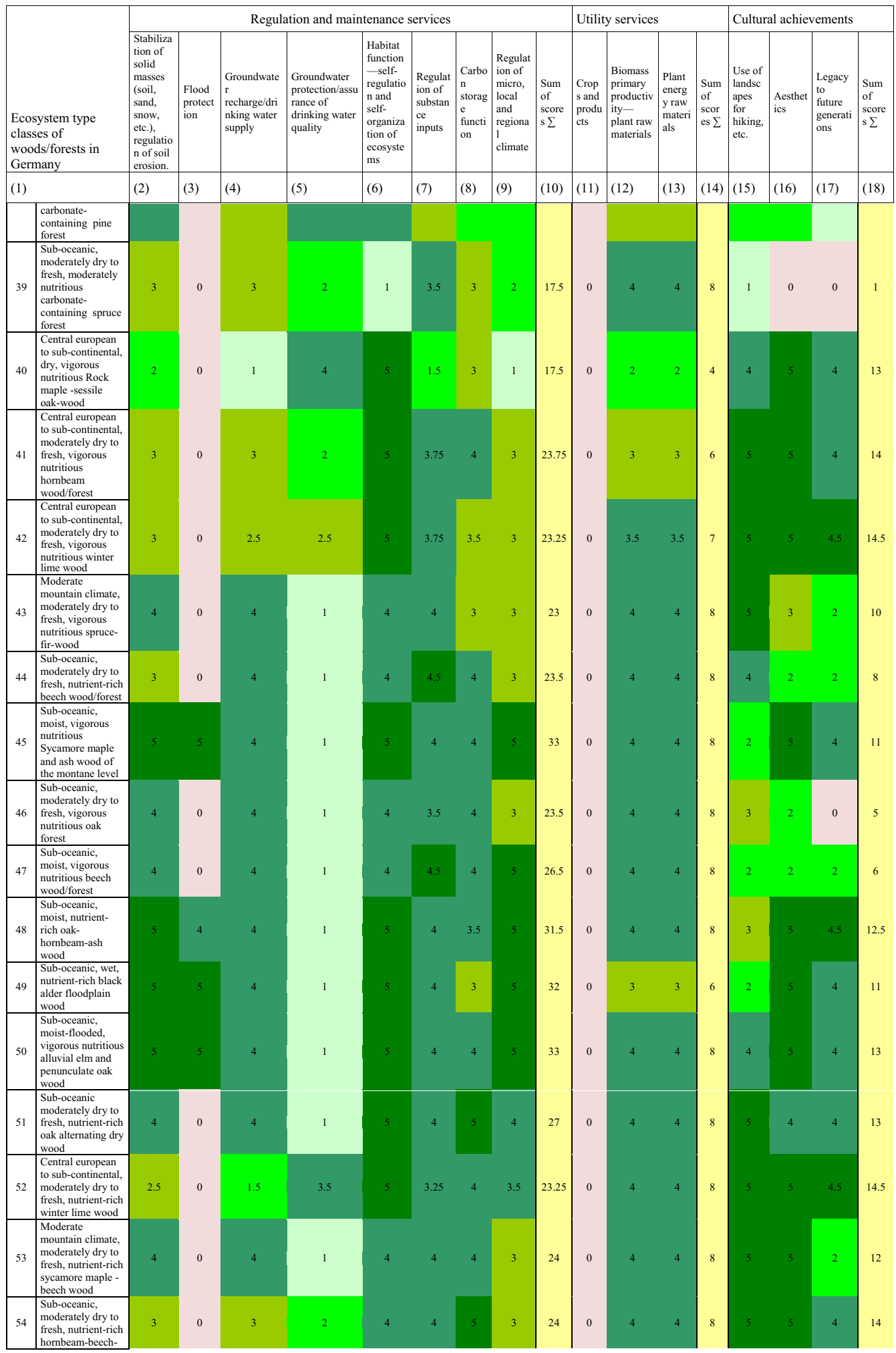


Table 21 (continued)

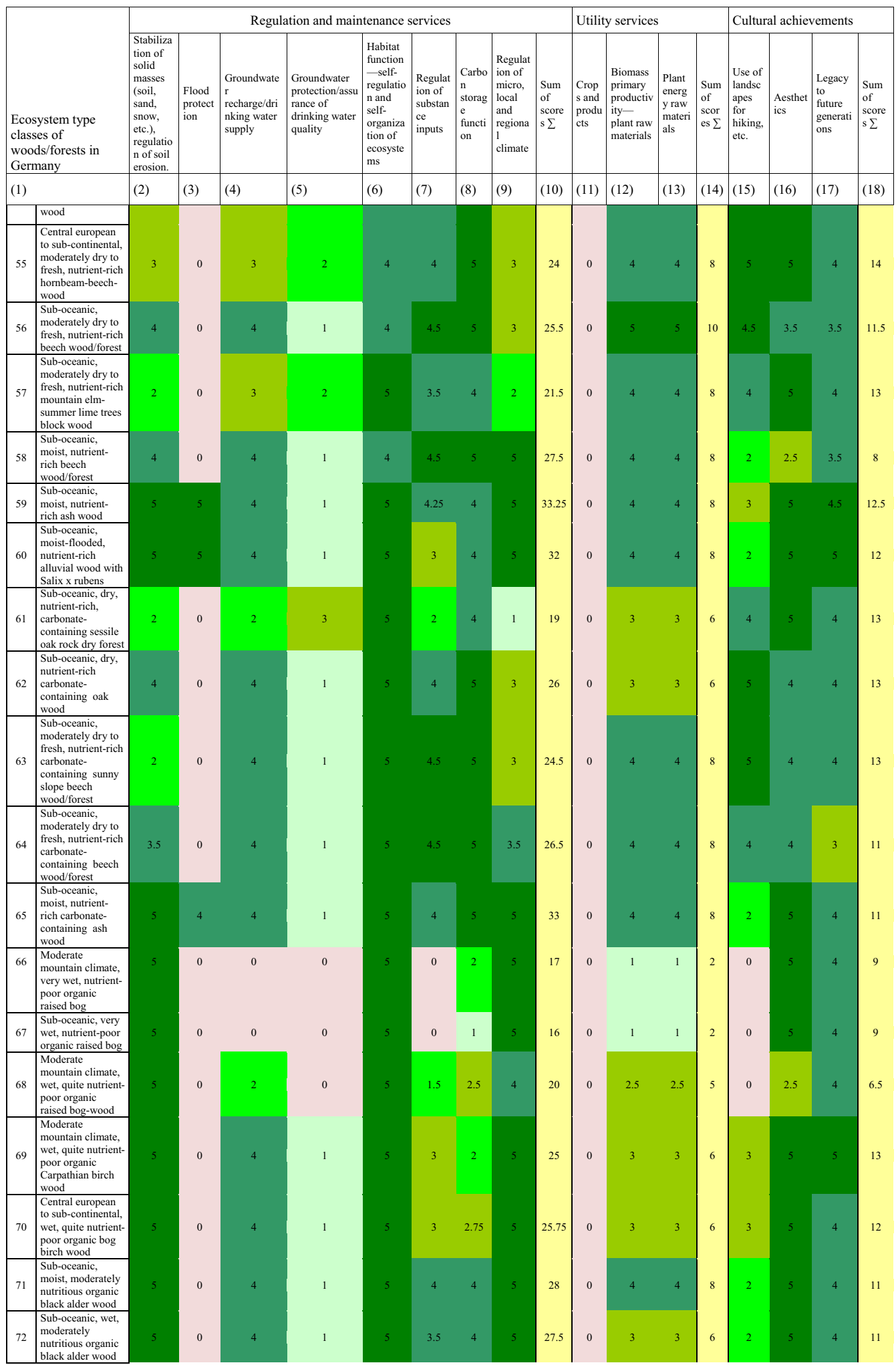


Table 21 (continued)

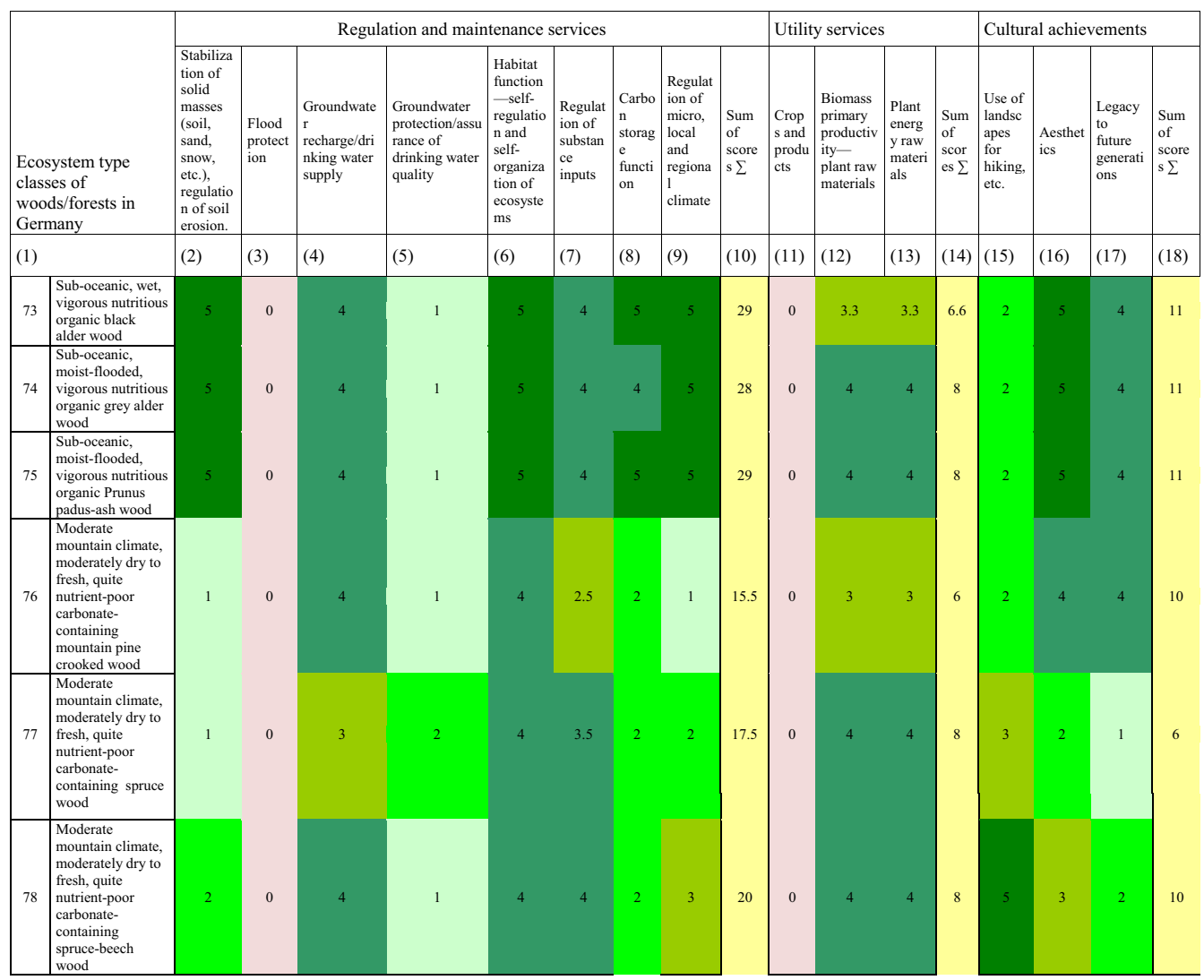

approx. 45,000 vegetation surveys with corresponding location characteristics and measured values from the neighbouring countries of Germany and other southern European countries. By linking the climate projections from dynamic modelling with the parameter ranges of the climate-ecological indicators of ecosystem types outside Germany, these climate change-related potentially near-natural ecosystem types can be identified and their reference status described accordingly. Similar projects already exist for some regions in Germany [54-59], which have already been successfully implemented in forest planning practice for climate-adapted forests. The corresponding experiences should be generalised and tested throughout Germany.

B: Complementing the current forest ecosystem types with open-land ecosystem types.

The BERN database $[54,60]$ offers representative information with currently 237 open land ecosystems with corresponding ecological characteristics and measured values. The open-land ecosystem types should be examined whether they should also be classified in parallel to the forest groups with regard to their function and services. A regionalisation of the forest ecosystem types to be expected in the course of climate change in Germany should be carried out: (1) Regionalisation of potential natural ecosystem types using the pnV map of Europe; (2) intersection of the map generated in this way with information from the European Environment Agency (EEA) on the current tree species distribution and land use; and (3) rule-based allocation and production of a map of ecosystems types in areas outside the extreme values of ecological site characteristics observed in Germany. On this basis, which should include possibly immigrating ecosystem types, the predictive mapping is then carried out according to Breiman et al. [61] and Pesch et al. [62, 63].

C: Linking soil chemical dynamic modelling with a dynamic vegetation model.

The dynamic modelling of soil chemical site indicators carried out by Schlutow et al. [64], including projections for the development of substance inputs and climate at 15 typical sites in Germany with VSD+ $[65,66]$, leaves room for interpretation as to whether and which developments in vegeta- 
tion are to be expected as a result of soil chemical changes. The answer to this question has far-reaching practical significance for forestry and agriculture, for green space and landscape planning and other users. Subsequently, the resulting time series of the soil chemical modelling at the representative sites are to be used as input data for the dynamic vegetation modelling. With its dynamic tool, the BERN model offers a proven basis for this $[54,60$, $67,68]$. The results will be interpreted and generalised where possible.

D: Derivation of measures for the regeneration of ecosystems with currently reduced integrity.

Various strategies for restoring the reference state can be derived from the degree of deviation of the current and future integrity from the reference state. For example, in the case of small deviations, the self-regeneration potential of the ecosystem may be sufficient, while large deviations may require renaturation measures. Within the framework of this work package, for each indicator, each function and ecosystem service, the degree of deviation at which the intensity of human influence is required for the regeneration of the reference state is to be estimated in a first step. This results in strategy categories. In the second step, concrete proposals for measures from practical nature conservation, forestry and agriculture, green planning and landscape planning are to be roughly described and assigned to the strategy categories.

\footnotetext{
Abbreviations

Al: Alluvial soils of broad river valleys including terraces and lowlands; BArtSchV: Federal Species Protection Ordinance; BERN: Model and database "Bioindication for Ecosystem Regeneration towards Natural conditions" [31, 32]; BÜK1000N: Reference soil profile of the land use-specified soil map 1:1,000,000 Germany [18]; C: Carbon; ${ }^{\circ} \mathrm{C}$ : Degree Celsius; C/N: Carbon/nitrogen ratio; Ca: Calcium; CEC: Effective cation exchange capacity; CICES: Common Classification of Ecosystem Services; CLC: Corine Landcover [17]; CLRTAP: Convention on Long-Range Transboundary Air Pollution; Corg: Organic carbon; D: Diluvial soils of the undulating lowlands and hilly areas; DWD: German Weather Service; ECOS: Ecosystem services; EC REG: Annex B VO 1332/2005 EC Species Protection Regulation; EEA: European Environmental Agency; EU: European Union; FFH DIRECTIVE: Fauna-Flora-Habitat Directive; FK: Field Capacity; Hh: Raised bog; Hn: Fen; K: Soils of coastal regions; Lö: Soils of the loess areas; Ls2-4: Weak to strong sandy loam; Lt2: Weak clayey loam; Lt3: Medium clayey loam; Lts: Sandy-clayey loam; Lu: Silty loam; MAES: Mapping and Assessment of Ecosystems and their Services [4]; N: Nitrogen; Na: Sodium; SI2: Light loamy sand; SI3: Medium clayey sand; SI4: Very loamy sandabbr; Slu: Silty-clayey sand; Ss: Pure sand; St2: Light clayey sand; St3: Medium clayey sand; Su2: Light silty sand; Su3: Medium silty sand; Su4: Strongly silty sand; T1: Loamy clay; Ts2: Slightly sandy clay; Ts3: Medium sandy clay; Ts4:Very sandy clay; Tt: Pure clay; Tu2-4: Weak to strong silty clay; Uls: Sandy-clayey silt; Us: Sandy silt; Ut2-4: Weak to strong clayey silt; Uu: Pure silt; V: Weathered soils of solid rock and their surrounding rock masses in mountainous and hilly areas; $V g$ : Rock-rich weathered soils of the high mountains; VSD+:Very Simple Dynamics Soil model, version 5.3.1.
}

\section{Supplementary Information}

The online version contains supplementary material available at https://doi. org/10.1186/s12302-021-00481-3.

Additional file 1: Table S1. Habitat requirements of selected species protected under EU law.

\section{Acknowledgements}

We thank Gudrun Schütze (Federal Environment Agency) for her constructive professional support of the project.

\section{Authors' contributions}

WS headed the investigation and drafted the manuscript. AS performed the rule-based ranking of ecosystem services. Both authors read and approved the final manuscript.

\section{Funding}

Open Access funding enabled and organized by Projekt DEAL. The studies were financed by the Federal Environment Agency.

Availability of data and materials

See Refs. [69, 70].

\section{Declarations}

Ethics approval and consent to participate

Not applicable.

\section{Consent for publication}

Not applicable.

\section{Competing interests}

The authors declare that they have no competing interests.

\section{Author details}

1 Öko-Data Ökosystemanalyse und Ökosystemdatenmanagement, Lessingstraße 16, 16356 Ahrensfelde, Germany. ${ }^{2}$ Chair of Landscape Ecology, University of Vecta, P.O.B. 1553, 49364 Vechta, Germany.

Received: 19 January 2021 Accepted: 16 March 2021

Published online: 19 April 2021

\section{References}

1. Jenssen M, Nickel S, Schröder W (2021) Methodology for classifying the ecosystem integrity of forests in Germany using quantified indicators. Environ Sci Eur. https://doi.org/10.21203/rs.3.rs-127444/v1

2. Jenssen M, Nickel S, Schütze G, Schröder W (2021) Reference states of forest ecosystem types and feasibility of biocenotic indication of ecological soil condition as part of ecosystem integrity and services assessment. Environ Sci Eur 33(18):1-18. https://doi.org/10.1186/s12302-021-00458-2

3. MEA (Millennium Ecosystem Assessment) (2005) Ecosystems and human well-being: synthesis. Island Press, Washington, DC

4. Schlutow A, Schröder W, Scheuschner T (2021) Assessing the relevance of atmospheric heavy metal deposition with regard to ecosystem integrity and human health in Germany. Environ Sci Eur 33(7):1-34. https://doi. org/10.1186/s12302-020-00391-w

5. EU (European Union) (2011) The EU biodiversity straegy to 2020. Publications Office of the European Union, Luxembourg. https://doi.org/10. 2779/39229. ISBN 978-92-79-20762-4

6. MAES (2016) Mapping and asssement of ecosystems and their services. http://biodiversity.europa.eu/maes. Accessed 25 July 2019

7. Maes J, Teller A, Erhard M, Liquete C, Braat L, Berry P, Egoh B, Puydarrieux P, Fiorina C, Santos F, Paracchini ML, Keune H, Wittmer H, Hauck J, Fiala I, Verburg PH, Condé S, Schägner JP, San Miguel J, Estreguil C, Ostermann 
O, Barredo JI, Pereira HM, Stott A, Laporte V, Meiner A, Olah B, Royo Gelabert E, Spyropoulou R, Petersen JE, Maguire C, Zal N, Achilleos E, Rubin A, Ledoux L, Brown C, Raes C, Jacobs S, Vandewalle M, Connor D, Bidoglio G (2013) Mapping and a ssessment of ecosystems and their services. An analytical framework for ecosystem assessments under Action 5 of the EU Biodiversity Strategy to 2020. Discussion paper-Final, April 2013. Publications office of the European Union, Luxembourg

8. Jacobs S, Burkhard B, Van Daele T, Staes J, Schneiders A (2015) 'The Matrix Reloaded': a review of expert knowledge use for mapping ecosystem services. Ecol Model 295:21-30

9. Burkhard B, Maes J (eds) (2017) Mapping Ecosystem Services. Pensoft Publishers, Sofia, $376 \mathrm{pp}$

10. Maes J, Liquete C, Teller A, Erhard M, Paracchini ML, Barredo Jl, Grizzetti B, Cardoso A, Som-ma F, Petersen J-E, Meiner A, Gelabert ER, Zal N, Kristensen P, Bastrup-Birk A, Biala K, Piroddi C, Egoh B, Degeorges P, Fiorina C, Santos-Martín F, Naruševičius V, Verboven J, Perei-ra HM, Bengtsson J, Gocheva K, Marta-Pedroso C, Snäll T, Estreguil C, San-Miguel-Ayanz J, Pérez-Soba M, Grêt-Regamey A, Lilleb Al, Malak DA, Cond S, Moen J, Czúcz B, Drakou EG, Zulian G, Lavalle C (2016) An indicator framework for assessing ecosystem services in support of the EU biodiversity strategy to 2020. Ecosyst Serv 17:14-23

11. Sohel MSI, Ahmed Mukul S, Burkhard B (2015) Landscape's capacities to supply ecosystem services in Bangladesh. A mapping assessment for Lawachara National Park. Ecosyst Serv 12:128-135

12. Science for Environment Policy (2015) Ecosystem Services and the Environment. In-depth Report 11 pro-duced for the European Commission, DG Environment by the Science Communication Unit, UWE, Bristol. http://ec.europa.eu/science-environment-policy

13. Schröder W, Nickel S (2020) Research data management as an integral part of the research process of empirical disciplines using landscape ecology as an example. Data Sci J 19(26):1-14. https://doi.org/10.5334/ dsj-2020-026

14. Haines-Young R, Potschin MB (2018) Common International classification of ecosystem services (CICES) V5.1 and guidance on the application of the revised structure. www.cices.eu

15. Albert C, Burkhard B, Daube S, Dietrich K, Engels B, Frommer J, Götzl M, Grêt-Regamey A, Job-Hoben B, Keller R, Marzelli S, Moning C, Müller F, Rabe S-E, Ring I, Schwaiger E, Schweppe-Kraft B, Wüstemann H (2015) Empfehlungen zur Entwicklung bundesweiter Indikatoren zur Erfassung von Ökosystemleistungen Diskussionspapier [Recommendations for the development of nationwide indicators for the assessment of ecosystem services. Discussion Paper]. BfN Skripten 410

16. Tung AKH (2009) Rule-based classification. In: Liu L, Öusu MT (eds) Encyclopedia of database systems. Springer, Boston. https://doi.org/10.1007/ 978-0-387-39940-9_559

17. Schröder W, Riediger J, Nickel S, Jenssen M (2016) Projektion zukünftiger Ökosystemzustände unter dem Einfluss von Klimawandel und atmosphärischen Stickstoffeinträgen. Integrität von Wald- und Forstökosystemen unter dem Einfluss von Klimawandel und atmosphärischen Stickstoffeinträgen - Teil II [Projection of future ecosystem conditions under the influence of climate change and atmospheric nitrogen inputs. Integrity of forest and forest ecosystems under the influence of climate change and atmospheric nitrogen inputs - Part II]. Naturschutz und Landschaftsplanung 48(1):22-28

18. DWD—Deutscher Wetterdienst (2012) Mittlere monatliche Niederschlagsmengen und Mittlere Tagesmitteltemperatur der Referenzperiode 1981-2010 für Sommer und Winter. Rasterdatei. [Mean monthly precipitation and mean daily temperature of the reference period 1981-2010 for summer and winter. Raster file]

19. BMVBS (Bundesministerium für Verkehr, Bauwesen und Städtebau) (2013) Untersuchung und Bewertung von straßenverkehrsbedingten Nährstoffeinträgen in empfindliche Biotope [Investigation and evaluation of road traffic-related nutrient inputs into sensitive biotopes]. Endbericht zum FEVorhaben 84.0102/2009 im Auftrag der Bundesanstalt für Straßenwesen, verfasst von Balla S, Uhl R, Schlutow A, Lorentz H, Förster M, Becker C, Scheuschner TH, Kiebel A, Herzog W, Düring I, Lüttmann J, Müller-Pfannenstiel K. In: Forschung Straßenbau und Straßenverkehrstechnik, Heft 1099, BMVBS Abteilung Straßenbau, Bonn. 362 S

20. AG Boden-Arbeitsgruppe Boden (2005) Bodenkundliche Kartieranleitung [Soil mapping guide]. 5. Aufl., Bundesanstalt für Geowissenschaften und Rohstoffe und den Geologischen Landesämtern der Bundesrepublik Deutschland (ed), Hannover

21. Schulze G (1998) Anleitung für die forstliche Standortserkundung im Nordostdeutschen Tiefland (Standortserkundung) - SEA 95 - Teil D. Bodenformen-Katalog, Merkmalsübersichten und -tabellen für Hauptund Feinbodenformen [Guidance for forest site reconnaissance in the Northeast German Lowlands (Site investigation). SEA 95 - Part D. Part D. Soil forms catalogue. Characteristic overviews and tables for main and fine soil forms 4. Aufl., Schwerin

22. Succow M, Joosten H (2001) Landscape ecology of peatlands. 2. Aufl., Schweizerbart'sche Verlagsbuchhandlung. Stuttgart. p 622

23. Succow M (1974) Landschaftsökologie der Moore. [Landscape-ecological moorland science]. PhD thesis. unpublished

24. Succow M (1988) Landschaftsökologische Moorkunde am Beispiel der Moore der DDR. [Landscape-ecological moorland science using the example of the moors of the GDR]. Gustav Fischer Publishing House, Jena, $340 \mathrm{pp}$

25. UBA - Umweltbundesamt (2015) Corine Land Cover - Bodenbedeckungsdaten für Deutschland [Land cover data for Germany] CORINE 2012, hochaufgelöste Version [high resolution version] LBM-DE2012 @ BKG/ Geobasis-DE

26. BGR (Bundesanstalt für Geologie und Rohstoffe) (ed) (2014) Nutzungsdifferenzierte Bodenübersichtskarte 1: 1000000 (BÜK1000N) für Deutschland (Wald, Grünland, Acker) [Land use-differentiated soil overview map 1:1 000000 (BÜK1000N) for Germany (forest, grassland, arable land)]. Hannover

27. Fröhlich and Sporbeck (2002) Leitfaden zur Erstellung und Prüfung Landschaftspflegerischer Begleitpläne zu Straßenbauvorhaben in Mecklenburg-Vorpommern. Erläuterungsbericht. Erstellt im Auftrag des Landesamtes für Straßenbau und Verkehr Mecklenburg-Vorpommern [Guidelines for the preparation and examination of landscape conservation plans for road construction projects in Mecklenburg-Western Pomerania. Explanatory report. Created on behalf of the State Office for Road Construction and Transport Mecklenburg-Vorpommern]. Bochum, Schwerin, 164 S

28. BMU (Bundesministerium für Umwelt, Naturschutz und Reaktorsicherheit) (2007) Nationale Strategie zur Biologischen Vielfalt (vom Bundeskabinett am 07.11.2007 beschlossen), Oktober 2007 [BMU (Federal Ministry for the Environment, Nature Conservation and Nuclear Safety Germany) (2007): National Strategy on biological Diversity. Bonifatius GmbH Paderborn, p 180]. https://www.bfn.de/fileadmin/ABS/documents/Biodiversi taetsstragie_englisch.pdf

29. Schlesinger WH (1990) Evidence from chronosequence studies for a low carbon-storage potential of soils. Nature 348:232-234

30. Grüneberg E, Riek W, Schöning I, Evers J, Hartmann P, Ziche D (2017) Kohlenstoffvorräte und deren zeitliche Veränderungen in Waldböden [Carbon stocks and their temporal changes in forest soils]. In: Wellbrock $\mathrm{N}$, Bolte A, Flessa $\mathrm{H}$ (eds) Dynamics and spatial patterns of forest locations in Germany. Results of the soil condition survey in the forest 2006-2008. Thünen Report 43, S. I-183 to I-209

31. Grabe M, Kleber M, Hartmann K-J, Jahn R (2003) Preparing a soil carbon inventory of Saxony-Anhalt, Central Germany using GIS and the state soil data base SABO_P. J Plant Nutr Soil Sci 166:642-648

32. Wiesmeier M, Prietzel J, Barthold F, Spörlein P, Geuß U, Hangen E, Reischl A, Schilling B, von Lützow M, Kögel-Knabner I (2013) Storage and drivers of organic carbon in forest soils of southwest Germany (Bavaria) -implications for carbon sequestration. For Ecol Manag 295:162-172

33. Blum W, Schad P, Nortcliff S (2018) Essentials of soil science Soil formation functions, use and classification (World Reference Base, WRB). Borntraeger Science Publishers, Stuttgart, p 171

34. Schachtschabel P, Auerswald K, Brümmer G, Hartke KH, Schwertmann U (1998) Lehrbuch der Bodenkunde [Textbook of soil science]. Verlag Ferdinand Enke, Stuttgart

35. Leuschner C, Wulf M, Bäuchler P, Hertel D (2013) Soil C and nutrient stores under Scots pine afforestations compared to ancient beech forests in the German Pleistocene: the role of tree species and forest history. For Ecol Manag 310:405-415

36. Nagel H-D, Becker R, Kraft P, Schlutow A, Schütze G, Weigelt-Kirchner R (2008) NFC Deutschland, Critical Loads, Biodiversität, Dynamische Modellierung [NFC. Germany, Critical Loads, Biodiversity, Dynamic Modelling] 
UBA-TEXTE 39/2008. https://www.umweltbundesamt.de/sites/default/ files/medien/publikation/long/3647.pdf. Accessed 25 July 2019

37. Bauer F (1953) Die Roteiche. D. Sauerländer'scher Verlag, Frankfurt a. M

38. Böckmann T (1990) Wachstum und Ertrag der Winterlinde [Growth and yield of the littleleaf linden] (Tilia cordata Mill) in Nordwestdeutschland. Dissertation Univ. Göttingen

39. Erteld W (1952) Die Robinie und ihr Holz [The Robinia and its wood]. Dt. Bauernverlag, , Berlin

40. Jüttner (1955) Ertragstafeln der Stiel- und Traubeneiche [Yield tables of pedunculate and sessile oak]. In: Schober R (ed) Ertragstafeln wichtiger Baumarten bei verschiedenen Durchforstungen [Yield tables of important tree species in different thinnings]. Verlag Sauerländer, Frankfurt a. M

41. Knapp E (1973) Ertragstafeln für Schwarzpappelsorten [Yield tables for black poplar varieties]. Forschungsbericht d. Instituts f. Rohholzerzeugung Abt. Waldbau/Ertragskunde, Eberswalde

42. Schober R (1967) Weißtanne, Europäische Lärche und Rotbuche [Silver fir, European larch and red beech]. In: Schober R (1975) Ertragstafeln wichtiger Baumarten bei verschiedenen Durchforstungen [Yield tables of important tree species in various thinnings]. J. D. Sauerländer's Verlag, Frankfurt a. M.

43. Schober R (1975) Ertragstafeln wichtiger Baumarten bei verschiedenen Durchforstungen [Yield tables of important tree species in different thinnings]. J. D. Sauerländer's Verlag, Frankfurt/M

44. Schober R (1987) Ertragstafeln wichtiger Baumarten [Yield tables of important tree species]. J. D. Sauerländer's Verlag, Frankfurt/M

45. Schwappach H (1912) Ertrags-Schätztafeln für Forstbestände [Yield estimation tables for forest stands]. Archiv der Forstwissenschaft Eberswalde, unveröffentlicht

46. Wiedemann F (1936) Ertragstafeln der Fichte [Yield tables of spruce]. In: Schober R (ed) Ertragstafeln wichtiger Baumarten bei verschiedenen Durchforstungen [Yield tables of important tree species in different thinnings]. Verlag Sauerländer, Frankfurt a. M

47. Wiedemann F (1943) Ertragstafeln der Kiefer [Yield tables of pine]. In: Schober R (ed) Ertragstafeln wichtiger Baumarten bei verschiedenen Durchforstungen [Yield tables of important tree species in different thinnings]. Verlag Sauerländer, Frankfurt a. M

48. Wimmenauer K (1919) Wachstum und Ertrag der Esche [Ash tree growth and yield]. Allgemeine Forst- und Jagd-Zeitschrift 90:9-17, 37-40

49. Amberger A (1988) Pflanzenernährung - Ökologische und physiologische Grundlagen, Dynamik und Stoffwechsel der Nährelemente [Plant nutrition-Ecological and physiological basics, dynamics and metabolism of nutrient elements]. Stuttgart: 3. überarb. Aufl., Verlag Eugen Ulmer, S. $118 \mathrm{ff}$

50. Hennings V (1994) Methodendokumentation Bodenkunde - Auswertungsmethoden zur Beurteilung der Empfindlichkeit und Belastbarkeit von Böden. Geologisches Jahrbuch, Reihe F, Schweizerbarthsche Verlagsbuchhandlung Stuttgart 13:194

51. Scheffer F, Ulrich B (1960) Humus und Humusdüngung [Humus and humus fertilization]. Zweite, völlig neu bearbeitete Auflage [Second, completely reworked edition]. Band I: Morphologie, Biologie, Chemie und Dynamik des Humus. Mit 45 Abbildungen und 39Tabellen. 1960. VII, 266 Seiten [Volume I: Morphology, Biology, Chemistry and Dynamics of Humus. With 45 figures and 39 tables. 1960. VII, p 266]

52. Müller L, Schindler U, Behrendt A, Eulenstein F, Dannowski R (2007) The Muencheberg soil quality rating (SQR). http://www.zalf.de/de/forsc hung/institute/lwh/mitarbeiter/lmueller/Documents/field_mueller.pdf. Accessed 25 July 2019

53. Schlutow A, Bouwer Y, Nagel H-D (2018) Critical Load Daten für die Berichterstattung 2015-2017 im Rahmen der Zusammenarbeit unter der Genfer Luftreinhaltekonvention (CLRTAP) [Critical load data for the Call for Data 2015-2017 of the Coordination Centre for Effects in the context of Germany's reporting obligations for the Convention on Long-Range Transboundary Air Pollution (CLRTAP)]. https://www.umweltbundesamt. de/publikationen/critical-load-daten-fuer-die-berichterstattung-2015

54. Schlutow A, Dirnböck T, Pecka T, Scheuschner T (2015) Use of an empirical model approach for modelling trends of ecological sustainability (Chapter 14). In: De Vries W, Hettelingh J-P, Posch M (eds) Critical loads and dynamic risk assessments: nitrogen, acidity and metals in terrestrial and aquatic ecosystems. Springer, p 662
55. Schlutow A, Becker R, Hübener P (2005) KliStWa - Einfluss regionalisierter Klimaprognosen und Stoffhaushaltssimulationen (dynamische Modellierung) auf den Stoffhaushalt repräsentativer Standorts- und Waldbestandstypen im Freistaat Sachsen. Online im Internet unter. http://www. umwelt.sachsen.de/Ifug/documents/Abschlussbericht_KliStWa_Teil_1. pdf. [KlistWa - Influence of Regionalized Climate Forecasts and Material Budget Simulations (Dynamic Modelling) on the Material Budget of Representative Site and Forest Types in the Free State of Saxony]. Dresden, $p$ 214

56. Schlutow A, Gemballa R (2008) Sachsens Leitwaldgesellschaften - Anpassung in Bezug auf den prognostizierten Klimawandel [Saxony's dominating forest associations - adaptation to predicted climate change]. Allgemeine Forstzeitschrift - Der Wald 1/2008, pp 28-31

57. Schlutow A, Kraft P, Weigelt-Kirchner R (2007) Veränderungen der potenziell natürlichen Vegetation im Zuge des Klimawandels im Freistaat Sachsen. Endbericht zum Forschungsvorhaben Nr. 40200317 im Auftrag des Staatsbetriebes Sachsenforst. Manuskriptdruck [Changes in potentially natural vegetation in the wake of climate change in the Free State of Saxony. Final report of the research project No. 40200317 on behalf of the Staatsbetriebes Sachsenforst. Graupa. Manuscript printing]. Graupa, $\mathrm{p}$ 187

58. Schlutow A, Profft I, Frischbier N (2009) Das BERN-Modell als Instrument zur Einschätzung der Angepasstheit von Waldgesellschaften und Baumarten an den Klimawandel in Thüringen [The BERN model as an instrument for assessing the adaptation of forest communities and tree species to climate change in Thuringia]. Forst und Holz 64:31-37

59. Schlutow A, Scheuschner T, Heinzel L, Schlutow M (2014) Anpassung von Klimagliederung und Leitwaldgesellschaften an den Klimawandel in Mecklenburg-Vorpommern. Projekt im Auftrag von Landesforst Mecklenburg - Vorpommern [Adaptation of climate structure and leading forest communities to climate change in Mecklenburg-Western Pomerania. Project commissioned by Landesforst Mecklenburg - Vorpommern], p 114

60. Schlutow A, Bouwer Y, Scheuschner T, Nagel HD (2017) Ermittlung und Bewertung der Einträge von versauernden und eutrophierenden Luftschadstoffe in terrestrische Ökosysteme [Identification and assessment of inputs of acidifying and eutrophying air pollutants into terrestrial ecosystems] (PINETI2)]. Teilbericht II. Critical Load, Exceedance und Belastungsbewertung. UBA-Texte 63/2017, pp 1-95

61. Breimann L (2001) Random forests. Mach Learn 45:5-32

62. Pesch R, Jerosch K, Schlüter M, Schröder W (2008) Using decision trees to predict benthic communities within and near the German Exclusive Economic Zone (EEZ) of the North Sea. Environ Monit Assess 136:313-325

63. Pesch R, Ranft S, Schröder W (2009) Predictive mapping of benthic habitats in the North Sea. Egypt J Aquat Res 35(3):281-289

64. Schlutow A, Schröder W, Jenssen M, Nickel S (2021) Modelling of soil characteristics a basis for projections of potential future forest ecosystem development under climate change and atmospheric nitrogen deposition. Environ Sci Eur 521:108-122

65. CCE (2012) Modelling and mapping of atmospherically-induced ecosystem impacts in Europe, CCE status report 2012, Coordination Centre for Effects, RIVM, Bilthoven, The Netherlands, $144 \mathrm{p}$

66. Posch M, Reinds GJ (2009) A very simple dynamic soil acidification model for scenario analyses and target load calculations. Environ Model Softw 24:329-340

67. De Vries W, Kros H, Reinds GJ, van Dobben H, Hinsberg A, Schlutow A, Sverdrup H, Butterbach-Bahl K, Posch M, Hettelingh J-P (2006) Improvement of steady-state and dynamic modelling of critical loads and target loads for nitrogen in Europe-Report critical N limits and loads CCE. Alterra, MNP-CCE

68. Schlutow A, Scheuschner T, Nagel H-D (2011) Development of vegetation under different deposition scenarios. In: Fischer R, Lorenz M (ed) Forest Condition in Europe - 2011 Technical Report of ICP Forests and FutMon. Online im Internet. http://www.icp-forests.org/pdf/TR2011.pdf. Accessed 25 July 2019

69. Jenssen M, Nickel S, Schröder W (2019) Einstufung der Ökosystemintegrität von Wäldern und Forsten Deutschlands auf Grundlage quantifizierter Indikatoren, Link zu Forschungsdaten und wissenschaftlicher Software [Classification of the ecosystem integrity of German forests 
based on quantified indicators, link to research data and scientific software] (Version v1). ZENODO. https://doi.org/10.5281/zenodo.2606380

70. Jenssen M, Nickel S, Schröder W (2019) 61 Referenzzustände zur Beurteilung der ökologischen Integrität von Wald- und Forstökosystemen, Link zu Forschungsdaten [Reference conditions for assessing the ecological integrity of forest ecosystems, link to research data] (Version v1). ZENODO. https://doi.org/10.5281/zenodo.2582888

\section{Publisher's Note}

Springer Nature remains neutral with regard to jurisdictional claims in published maps and institutional affiliations.

\section{Submit your manuscript to a SpringerOpen ${ }^{\odot}$ journal and benefit from:}

- Convenient online submission

- Rigorous peer review

- Open access: articles freely available online

- High visibility within the field

- Retaining the copyright to your article

Submit your next manuscript at $\boldsymbol{\nabla}$ springeropen.com 